\title{
Hjemstavnskultur og byggeskik i Slesvig-Holsten
}

\author{
af HANS-GÜNTHER ANDRESEN
}

Over hele Europa opstod omkring 1900 en reaktion mod 1800-tallets arkitektur og boligkultur, der efterlignede de store stilepoker fra det sydlige udland. Bevægelsen for en hjemlig byggeskik slog særlig stærkt an i Slesvig-Holsten, hvor der siden 1890 var opbygget en ny regional selvbevidsthed over for den fælles preussisk-tyske kultur. Bærende for de nye idéer blev Heimatschutzbevægelsen, som tog vare på hjemstavnskulturværdierne. Centrum for bevægelsen i Slesvig-Holsten blev Tønder med den succesrige forening til bygningsbevaring og bedre byggeskik, Baupflege Kreis Tondern, stiftet i 1907 en forening, som i løbet af få år fik sat sit afgørende stempel på alt privat og offentligt byggeri i Vestslesvig. Men Tønderegnen fik også afgørende betydning for skabelsen af en ny dansk bedre byggeskik, idet det var her en række unge arkitekter fandt inspirationen til en ny national arkitektur. En ældre arkitekt bemærkede i 1910 sarkastisk, at doktrinen nu lød: »Ned med Italien, leve Møgeltønder «. Resultatet var, at Danmark og Slesvig-Holsten ved genforeningen i 1920 prægedes af et næsten identisk arkitekturideal - så de danske arkitekter, der ville »udrydde al tysk smag «, på en måde løb en åben dør ind. Denne historie har været næsten upåagtet, selv om nogle af den slesvigholstenske Heimatschutz-arkitekturs vigtigste monumenter befinder sig i det nu danske Nordslesvig.

„Vore huse skal være selvfølgelige og naturlige!« Dette klare og pædagogisk formulerede opråb, som arkitekt Ernst Prinz fra Kiel kom med i 1911, kunne arkitekter både i Heimatschutz-bevægelsen og den beslægtede Bedre Byggeskik-bevægelse i Danmark (stiftet 1915) tilslutte sig. Men det, som lød så enkelt, lod sig ikke gennemføre uden kamp efter den historiske stil-arkitekturs lange herredømme. Stil-arkitekturen var kommet til Nordtyskland fra akademierne, de tekniske skoler og højskoler og herskede endnu uhindret omkring 1900. I Danmark skete opgøret med den stilefterlignende arkitektur tidligere og lettere - blandt andet foranlediget af arkitekt Martin Nyrop, som allerede $i$ lobet af $1890^{\prime}$ erne havde lagt fundamentet til en bygningskulturel fornyelse.

Karl Meyer, som var stadsarkitekt i Kiel og særlig engageret i byg- 
ningsbevægelsen, udtrykte dens idégrundlag således: Heimatschutzbevægelsen i Slesvig-Holsten ser ikke sikringen af en bedre byggeskik $i$ en slavisk gentagelse af de gamle former. Vor tids gode bygninger skal være absolut hensigtsmæssige og ubetinget opfylde alle de behov, som den nye livsstil, sundhedslæren og de funktionelle krav stiller. Der må derfor gives afkald på mangen god, ærværdig tradition, som er $\mathrm{i}$ modstrid hermed. Men på den anden side er en reform af byggeskikken umulig for Heimatschutz-bevægelsen, hvis det ikke lykkes igen at opsamle overleveringens tabte tråd (1914). ${ }^{1}$

Karl Meyer havde i 1909 gjort sig bemærket som udgiver af den

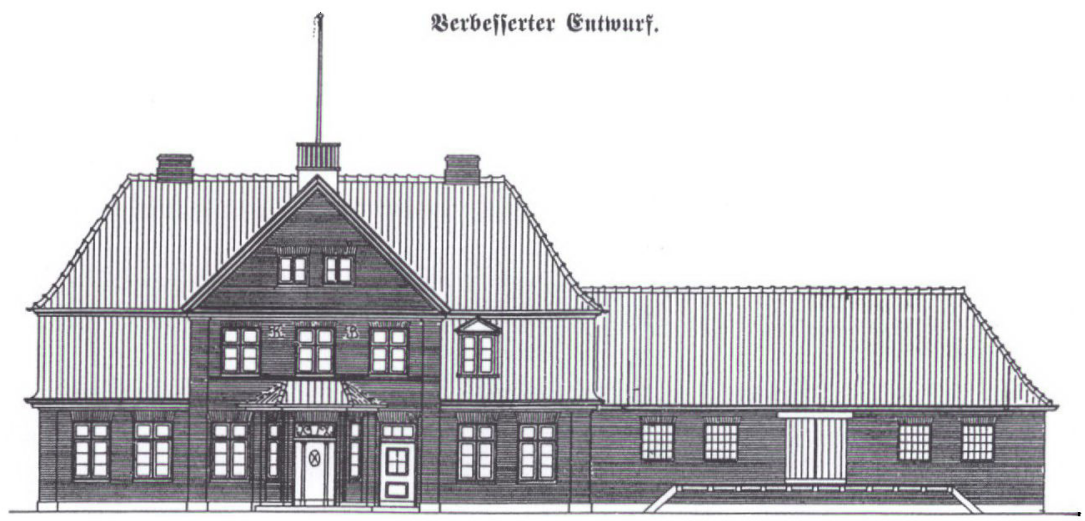

Ansicht von der Straße.

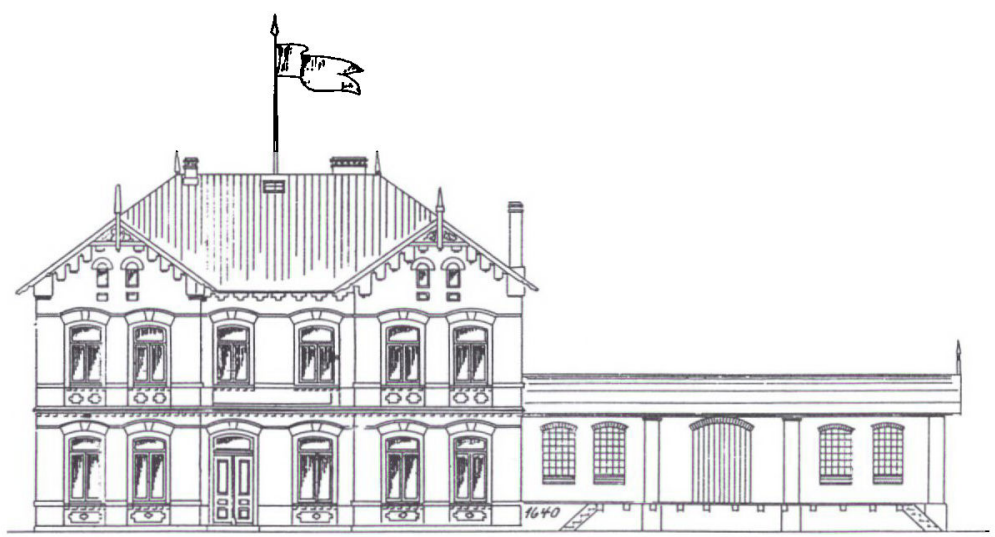

"Forbedret udkast « af Carl Meyer, 1910, til Kleinbahnhof $i$ Kirchbarkau. For neden det første og afviste "stilløse" udkast. Fra: "Ländliche Bauten in Schleswig-Holstein" 1914. 


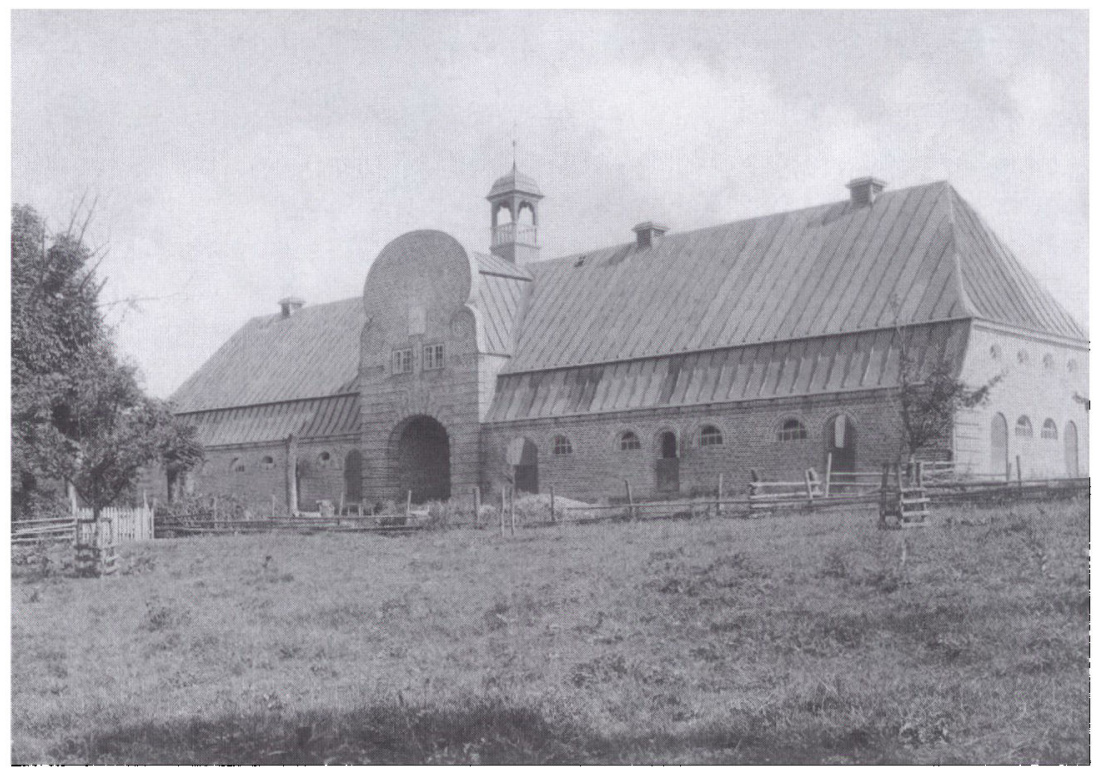

Porthus til godset Schönhagen, opført 1913 af Ernst Prinz (ældre foto).

berømte Baukatechismus, der i et forståeligt sprog søgte at sætte nye tidløse normer for godt byggeri, og som blev udgivet $i$ flere oplag. Han havde $\mathrm{i}$ årevis ansvaret for Heimatschutz-bevægelsens "tekniske forvaltning « i Kiel og udgav i 1914 på denne baggrund den store eksempelsamling Ländliche Bauten in Schleswig-Holstein ${ }^{3}$. Ernst Prinz, som i 1907 var kommet til Kiel efter uddannelse på den tekniske højskole i Karlsruhe, avancerede hurtigt til at blive én af Slesvig-Holstens førende privatpraktiserende arkitekter. Sin arkitektoniske grundholdning havde han fra arkitekt og professor Herman Billing, hos hvem han var i lære, og som 1907-10 byggede det mægtige rådhus i Kiel i en moderne blanding af jugendstil og barok. Ernst Prinz var fra starten medlem af Heimatschutz, og han blev desuden hurtigt optaget i det progressive, i 1903 stiftede Bund Deutscher Architekten (BDA) og endelig også i Deutsche Werkbund (stiftet 1907 og et sidestykke til den danske Skønvirke-bevægelse). Prinz opfattede sit arbejde for en reform af bygningskulturen omkring 1910 som en forening af disse tre bestræbelser. 


\section{Heimatschutz og Baupflege i Slesvig-Holsten}

Begrebet Heimatschutz var idé- og kulturhistorisk et "åndeligt barn « af den almene kultur- og reformbevægelse omkring 1900. Heimatschutz-bevægelsen havde et bredt virkefelt og omfattede $i$ virkeligheden de samme beskyttelses- og bevaringstanker, som man i dag kender i miljøbevægelsen. Men den vigtigste opgave, især i Slesvig-Holsten, blev reformen af bygningskulturen. I de år, hvor Heimatschutzbevægelsen fik rodfæste, blev den et uafhængigt modstykke til den officielle "Denkmalschutz" (bygningsbevaring). Den kom på den måde til at virke i en frugtbar alliance med den ovennævnte avantgarde $i$ arkitekturen og som en slags reformbevægelsens "regionale arm «. Heimatschutz-bevægelsen var så at sige bygningskulturens græsrodsbevægelse - men den nød hurtigt godt af en omfattende offentlig støtte.

Der lå i tiden en udbredt sympati for ånd og stil fra tiden omkring 1800 , men det betød ikke, at den nye bevægelse alene flygtede fra nutiden eller dyrkede det nostalgiske tilbageblik. Imod dette talte allerede tilknytningen til BDA og Deutsche Werkbund, og citatet af Karl Meyer bekræfter det samme: Heimatschutz holdt sig - også, eller netop i Slesvig-Holsten - stort set fri fra fristelsen til kun at kaste glans over en reform af den moderne civilisation ved hjælp af den førindustrielle kultur.

»Vi kræver pleje af hjemstavnen!« Sådan lød det 1903 i en appel til stiftelse af et tysk forbund for Heimatschutz, som 1904 blev iværksat i Dresden under ledelse af Ernst Rudorff og Paul Schulze-Naumburg for at "beskytte den tyske hjemstavns naturlige og historiske egenart gennem en samling af alle hjemstavnsbevægelser«. Denne opfordring blev også fulgt nord for Elben, hvor de forskellige lokale Heimatschutz-bestræbelser ret hurtigt blev organiseret efter dannelsen af den tyske centralorganisation i Meiningen i Thüringen 1904. I Lübeck stiftedes således allerede 1907 Verein für Heimatschutz Lübeck og i oktober 1908 Schleswig-Holsteinische Landesverein für Heimatschutz med godsejeren, juristen og historikeren Paul v. Hedemann-Heespen i bestyrelsen og med kraftig opmuntring fra von Bülow, præsident for provinsregeringen i Slesvig. I november $1908 \mathrm{blev}$ foreningen Baupflege Kreis Tondern så stiftet. Den holdt sig - muligvis af nationalpolitiske grunde - uafhængig af landsforeningen, som man dog lagde vægt på at være $\mathrm{i}$ god forbindelse med. Initiativet kom fra 


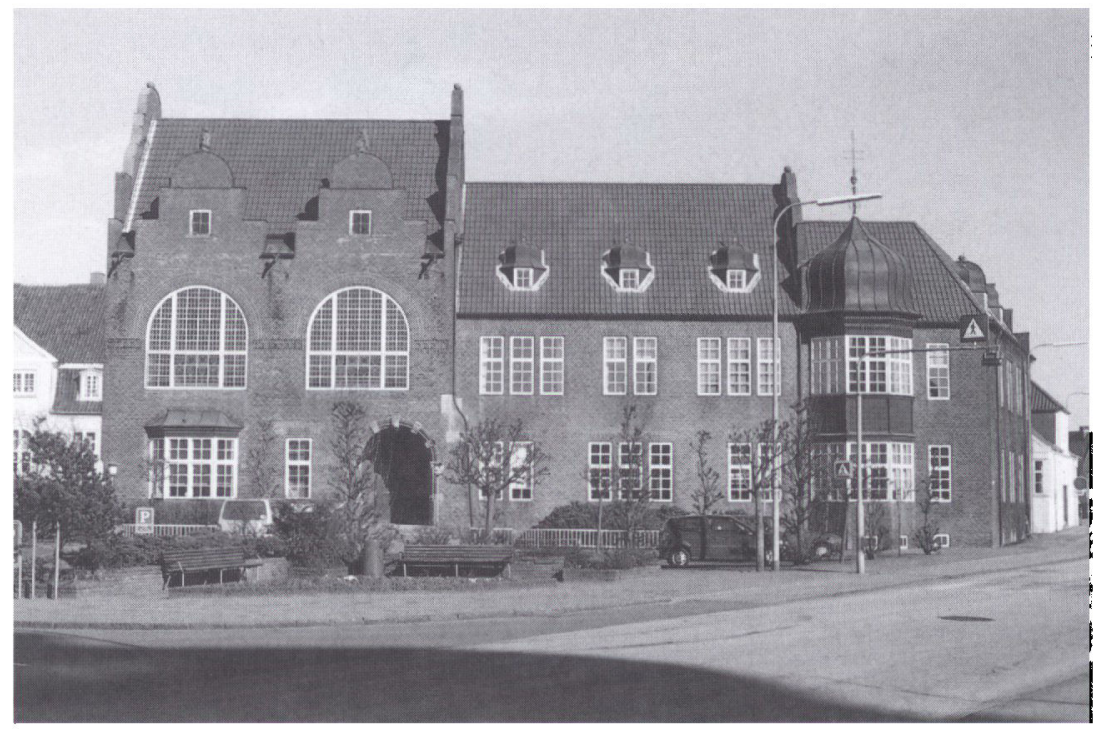

Tonder. Kredshuset, bygget 1905-07 af Dinklage, Paulus og Lilloe. Nu amtets administrationsbygning. Nutidigt foto.

kredsråd Friedrich Rogge, som energisk ledede "sin « hurtigt berømte forening for bygningsbevaring og byggeskik. Baupflege Kreis Tondern kom nemlig på afgørende vis til at præge bygningskulturen i hele den vestslesvigske marskegn. Starten på dette arbejde var på en måde allerede taget i 1905 med konkurrencen om det nye kredshus i Tønder og valget af arkitekterne Paulus, Dinklage \& Lilloes projekt i hollandsk-frisisk stil. Dette fornemme bygværk kom som forbillede til at "stråle ud i hele det flade land", og blev for hele Nordtyskland et første eksempel på en fri genoptagelse af traditionen fra »den hjemlige byggeskik«.

I 1908 begyndte også Baupflege-foreningen i Süderditmarschen sit arbejde under ledelse af den stedlige kredsråd og kredsbygmester. Og 1910 stiftedes Ortsgruppe Heimatschutz für den Kreis Herzogtum Lauenburg und Umgebung. I Haderslev stiftedes samtidig endnu en Baupflege-forening, der som forbilledet i Tønder lagde vægt på uafhængighed af landsforeningen for Heimatschutz. I 1911 fulgte lokalgruppen i Neumünster; nærmere betegnet Verein Heimatschutz, Ortsgruppe für Neumünster und Kreis Bordesholm. I industribyen Neumünster kunne foreningen snart henvise til forbilledlige nye byg- 


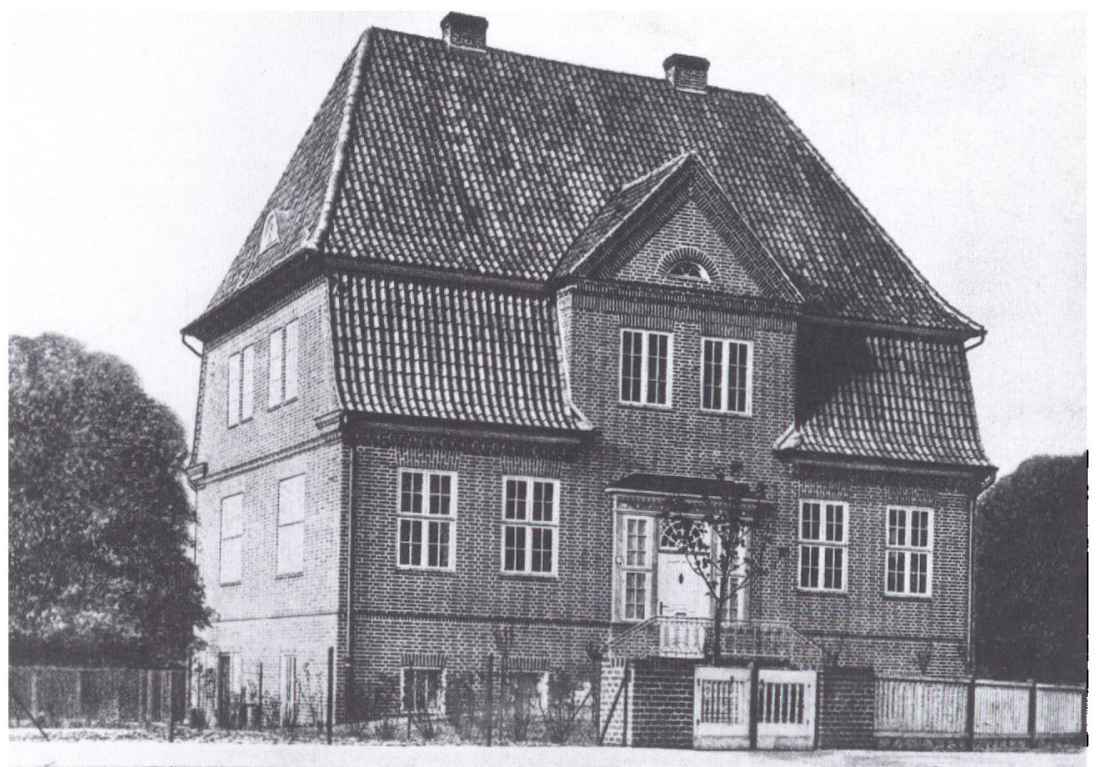

Neumünster. Villa "Marggraf", bygget 1913 af Hans Ross. Fra: "Moderne Bauformen $\approx 1920$.

ningsværker, f.eks. af den privatpraktiserende arkitekt Hans Ross eller af stadsbygmester Paul Reese. Stadsarkitekten i Bordesholm Amt, Johann Garleff, der som Prinz bl.a. var uddannet i Karlsruhe, kom også som næsten ene mand til at præge egnen med en lokal forankret arkitektur og fik ansvaret for bygningspolitikken i hele amtet. På lignende måde som i Tønder blev det nye kredshus i Bordesholm fra 1912-13 et eksemplarisk og betydningsfuldt forbillede. Garleff tegnede denne solide og festlige bygning som en næsten Heimatschutzideel mellemting mellem en repræsentativ offentlig bygning og et privat landsted, følsomt tilpasset de tre hovedudsigter - mod søen, mod markerne og mod vejen - uden at svække helhedskarakteren.

\section{Den nye generation af arkitekter og deres forbilleder}

Årene 1907 og 1908 blev altså vendepunktet for bygningskulturen i Slesvig-Holsten, som $\mathrm{i}$ over to årtier og tildels også endnu længere kom til at stå i Heimatschutz's tegn. Dette betød dog ikke, at den slesvig-holstenske arkitektur kun blev »provinsiel«, tværtimod: Net- 


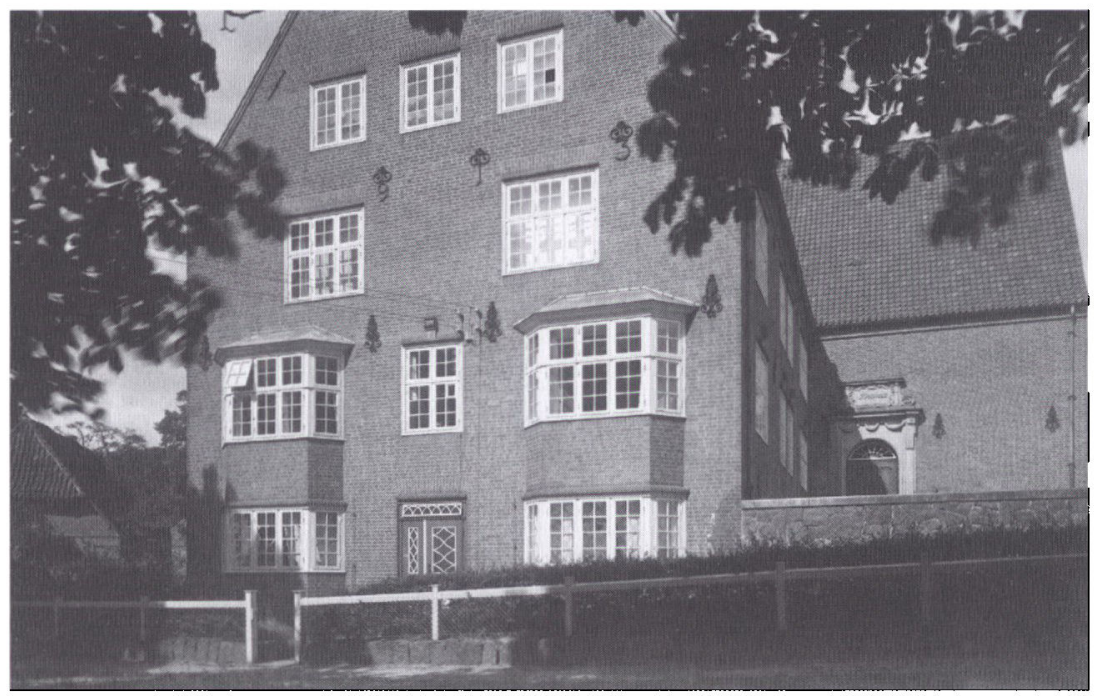

Bordesholm. Det tidligere kredshus, bygget 1912-13 af Johann Garleff, med den karnapprydede gavl, inspireret af gammel Tonder-byggeskik (ældre foto).

op den nye »hjemlige« arkitektur bidrog i høj grad til, at den preussiske provins Slesvig-Holsten i det mindste kulturelt blev et selvstændigt »land «. Netop 1907-08, samtidig med f.eks. Ernst Prinz, Heinrich Stav eller Johann Garleff, fik også den yngre generation af slesvigholstenske arkitekter (født i 1870'erne) fodfæste, hvor f.eks. Johann Theede, Ernst Stoffers, Hans Schnittger eller den fra Sylt stammende Heinrich Bomhoff nu startede deres karriere. 1908 bosatte Lauritz Thaysen sig i Tønder og blev fra starten den førende arkitekt på egnen, helt $\mathrm{i}$ overensstemmelse med Baupflege Kreis Tondern's ånd. I billedet hører også, at den tekniske skole i Eckernförde netop i 1908 besluttede at virke for den nye hjemlige bygningskultur med basis $\mathrm{i}$ »det overleverede by- og landskabsbillede«.

Arkitekterne $\mathrm{i}$ den nye bygningskultur-bevægelse var påfaldende hyppigt dimittender fra sydtyske arkitektskoler som Karlsruhe, Darmstadt, Stuttgart, München eller Dresden. Disse skoler ansås dengang for at være mere progressive end skolerne i Berlin eller Hannover, der alt for længe vedblev med at være dogmatiske højborge for 1880 'ernes nygotiske murstensarkitektur. Arkitekteleverne fra Slesvig-Holsten, eller de reformivrige yngre arkitekter fra Sydtyskland, der som Carl Mannhardt eller Paul Ziegler (mangeårig stads- 


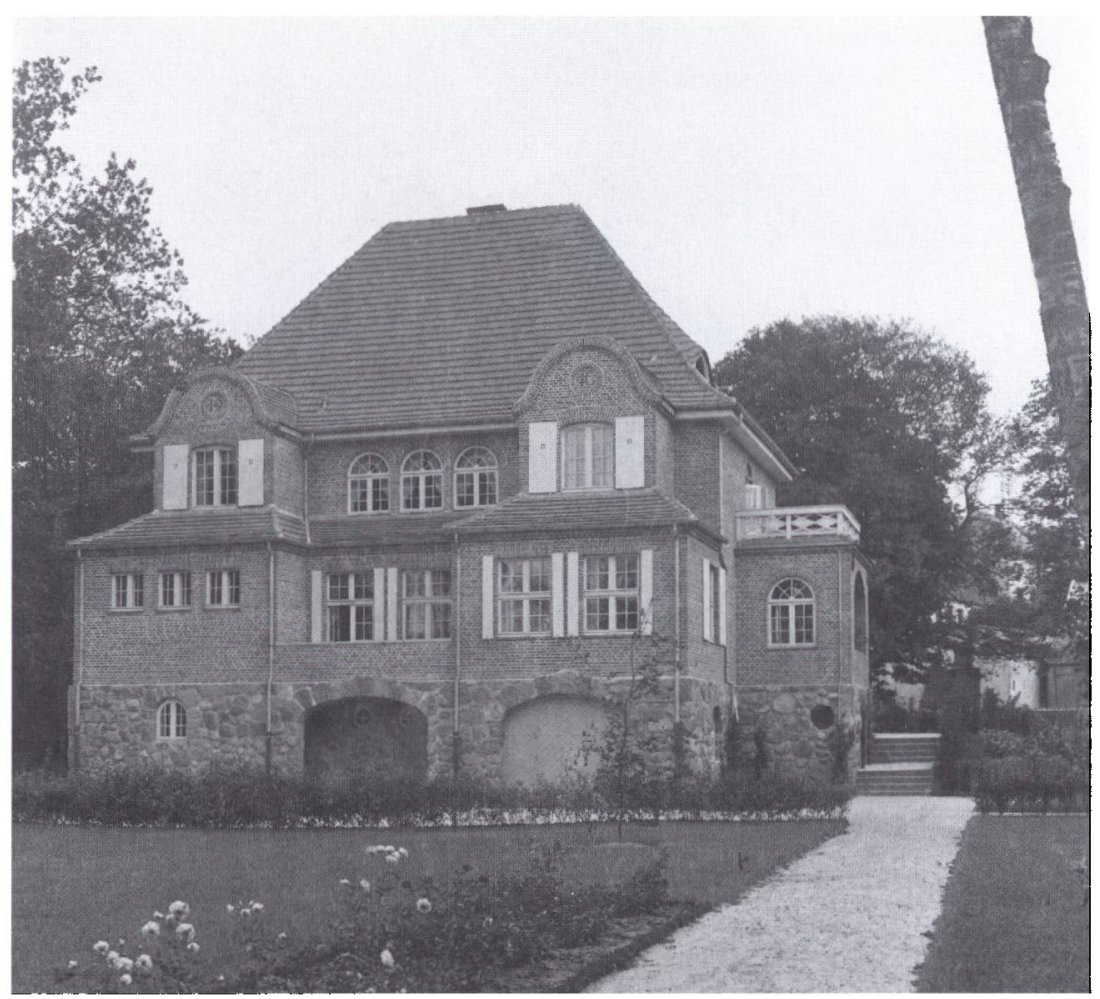

Villa for Dr. Sievert $i$ Tonder, opfort 1910 af Professor Anton Huber, Kunstgewerbeschule Flensburg (ældre foto).

bygmester i Flensborg) havnede i området nord for Elben, blev netop gennem det traditionsbundne sydtyske puds- og kvaderstensbyggeri og gennem mødet med den sydtyske barokstil ansporet til at overføre formprincipperne herfra til både det nye monumentalbyggeri og det hjemlige murstensbyggeri. Hovedprincipperne var fasthed og klarhed: koncentration om det væsentlige, så vidt muligt blokagtigt sluttede bygningsdele under tilsvarende store og udelte tagflader, med vidtgående afkald på de maleriske tilføjelser, som havde været så yndede omkring 1900. Til den nye stil hørte også en renæssance for den traditionelle bygningskolorit, frem for alt harmonien mellem grundfarverne rød, hvid og grøn, som i dag opfattes som den karakteristiske farvetrio i det slesvig-holstenske Heimatschutz-byggeri. Karakteristisk for den nye stil blev de røde mure og de røde tegltage, men også de sortglaserede teglstenstage, som kendes fra 16-1700-tallets ar- 


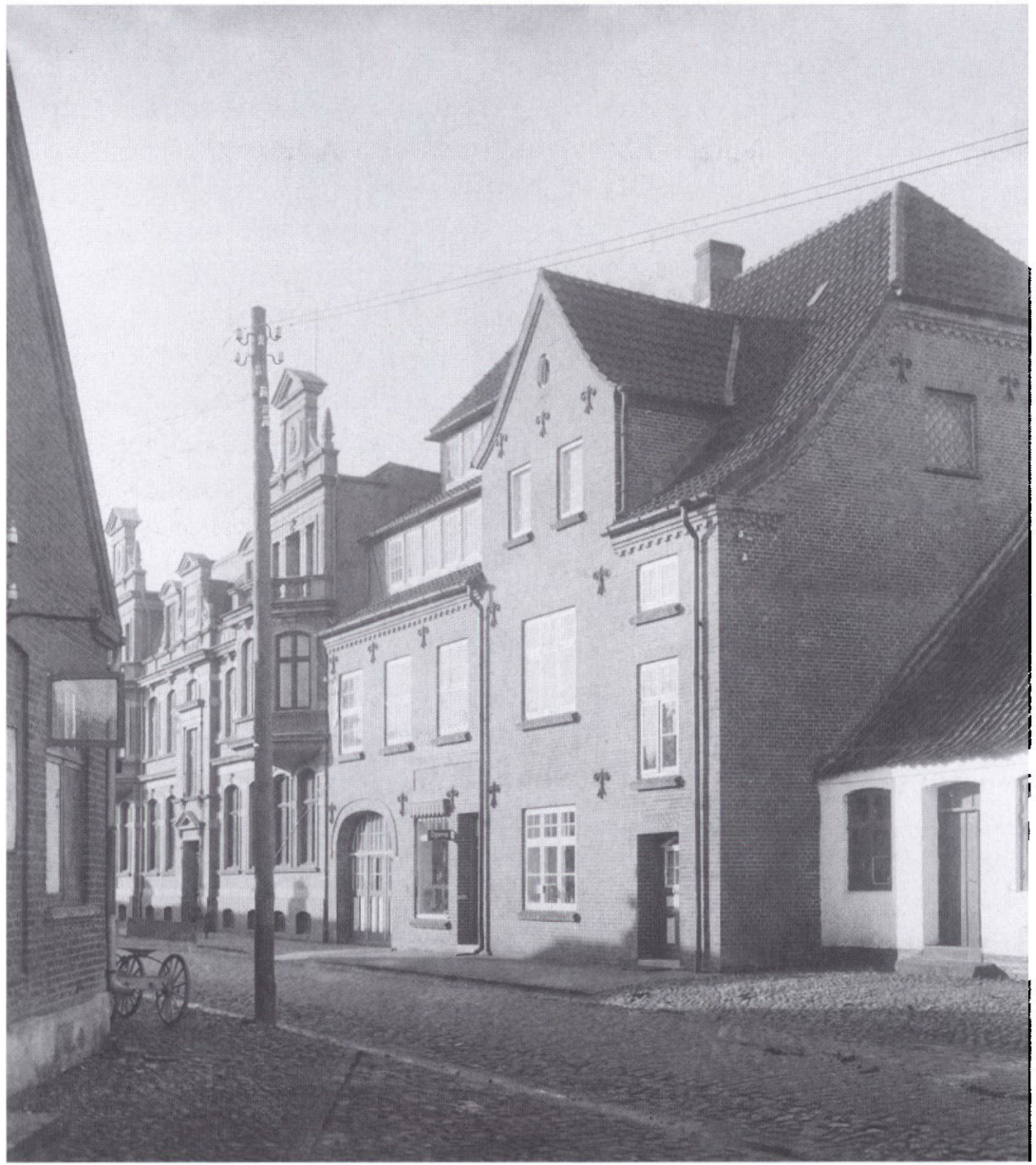

Logumkloster. Nyopfort forretningsejendom for M. Bock, tegnet af arkitekt Carl Voss, Kiel. Fremhavet $i$ Kunstkalender som et positivt »eksempel over for »modeksemplet " t.v. herfor fra 1890'erne (ældre foto).

kitektur i Danmark og hertugdømmerne. Dertil kommer det hvide i vinduesrammerne og på taggesimserne, stakitter, espalierer og endvidere det grønne på døre, porte, stolper, skodder og yderkarme. Og endelig det kobbergrønne på hus- og karnaptagene eller det naturgrønne på stråtagene og i klatreplanterne.

På den måde kom den nye generation af slesvig-holstenske arkitekter til at udvikle en selvstændig og for landet karakteristisk ny arki- 
tektur, baseret på traditionen. En vigtig inspirationskilde var også det senbarokke murstensbyggeri i Slesvig-Holsten, skabt af arkitekter som Sonnin, Dallin, Greggenhofer, Rosenberg eller Richter. Det var denne arkitektur fra tiden omkring 1800, der blev betragtet som den sidste epoke, hvor landsdelen havde en fælles og karakteristisk stil, som kunne fungere som forbillede for de mange nye byggeopgaver. Schulze-Naumburg talte med øje for denne forbilledlige-epoke atter og atter om eksemplerne på de "gode gamle bygningsformer ...", som han med sin hurtigt berømte metode konfronterede med de samtidige "modeksempler«. Interessen for tiden skærpedes af den i 1908 af arkitekt Paul Mebes udkomne bog med den programmatiske titel $U m$ $1800 .^{5}$ Samme år offentliggjorde arkitekten Carl Zetzsche sit store samleværk Zopf und Empire von der Wasserkante ("parykstil«, dvs. rokoko, og empire ved nordkysten), hvor han fremhævede den »kunstneriske betydning ved de helt igennem enkle, men med deres strenge saglighed og fornemme opdeling dobbelt virkningsfulde teglbygninger «. Mens "man dengang i hele det øvrige Tyskland nærmest skammede sig over murstenene", var de ifølge Zetzsche både i SlesvigHolsten og Danmark blevet anvendt "mesterligt i overensstemmelse med den herskende stil, således at murstensbygningerne dér $\mathbf{i}$ stor udstrækning overgår de samtidige pudsede bygninger $i$ indre værdi som i totalvirkning. ${ }^{6}$

Den nye arkitektgeneration, som inden længe havde etableret sig, skabte bemærkelsesværdigt hurtigt et nyt bygningssprog, som - undertiden tilføjet lidt landlig dialekt - faktisk blev både et arkitektonisk højsprog og samtidig på en måde "plattysk « daglig tale. Det nye sprog bidrog væsentligt til, at de tidligere hertugdømmer fandt deres egen kulturelle identitet eller snarere genfandt sig selv. Dertil bidrog nu også mere og mere de preussiske eller kejserlige byggemyndigheder, hvis yngre tjenestemænd sluttede op om den nye murstensarkitektur, som uanset byggeopgave tilpassede sig den lokale tradition. Den såkaldte "Verunstaltungsgesetz (lov imod vansirende byggeri, reklamer og skure i by og på land) fra 1907, som trods sit navn gav et godt retsligt grundlag for en ny landskabelig byggepolitik, fremmede helt sikkert sagen. En stor succes blev også det kejserlige kanalkontors sociale byggeri af arbejder- og funktionærboliger "tværs gennem landet « ved Kaiser-Wilhelm-kanalen (Kielerkanalen). Her forenedes byggeskikarbejde og landskabsbevaring på en næsten ideel måde. Opgaven var her at indføje det drastiske indgreb i det histori- 
Flensborg. Auguste-Viktoria-skolen (tidl. pigegymnasiet), bygget 1910-12 af Paul Ziegler som en del af den nye »bykrone" på hojdedraget vest for den indre by.

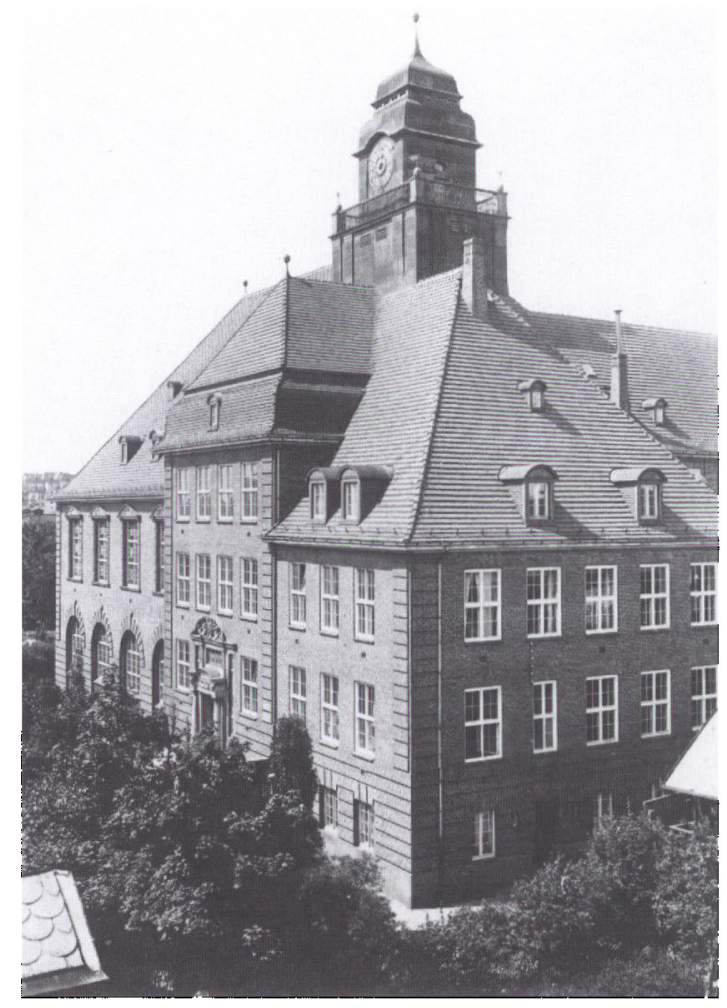

ske kulturlandskab med respekten for den lokale byggetradition. Manden bag byggeriet var statsarkitekt Charton, som allerede i 1911 i 1. årgang af Schleswig-Holsteinische Kunstkalender bekendte sig til Heimatschutz-bevægelsens idealer. Hans efterfølger Ewald Klatt, som senere blev bygningsrådgiver for staten, fortsatte på eksemplarisk vis med dette arbejde under 1. verdenskrig og ind i 1920'erne.

Allerede omkring 1910-12 stod den nyere slesvig-holstenske arkitektur på et godt og bredt murstensfundament, på hvilket der blev bygget videre $i$ endnu to årtier $i$ næsten uafbrudt kontinuitet. Den nye arkitektur fik i 1912 god reklame med den store byggeudstilling på Flensborg Museum, som museets leder Ernst Sauermann (senere landsantikvar og direktør for Thaulow-Museet i Kiel) organiserede på vegne af Landesverein für Heimatschutz. ${ }^{7}$ Det blev en sand kraftpræstation af den nordelbiske Heimatschutz-arkitektur, hvori bl.a. deltog Baupflege-foreningerne i Tønder og Haderslev. Særlig udførlig præ- 


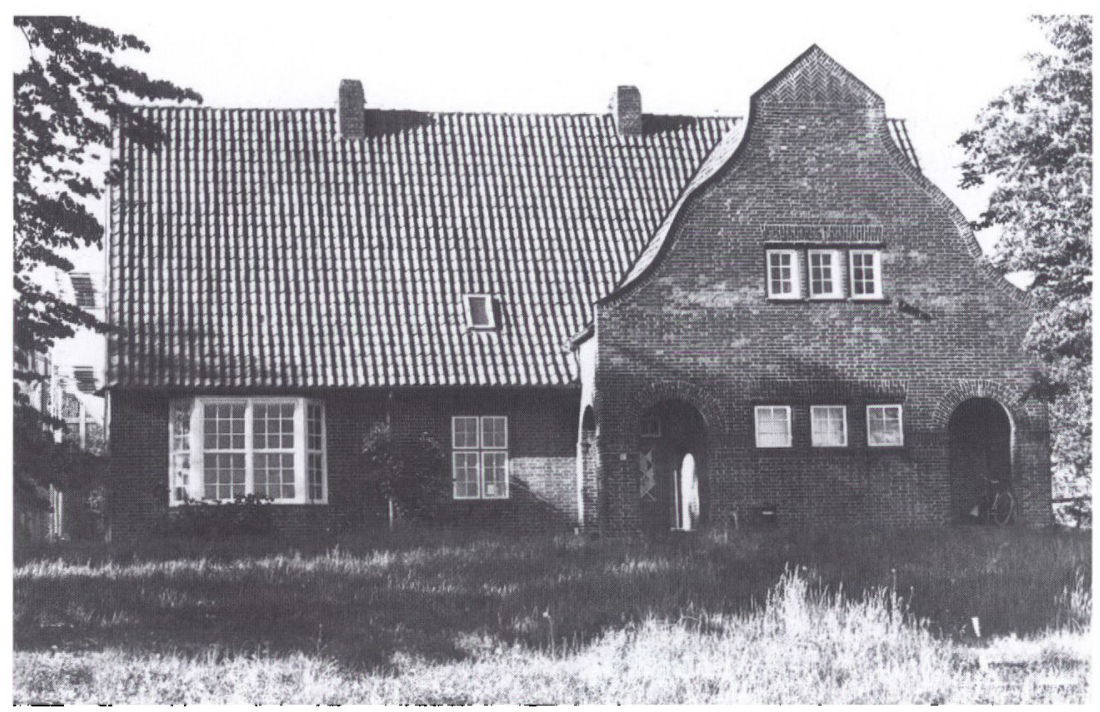

Én-klasset folkeskole med lærerlejlighed i Bissee, Kreis Bordesholm (i dag Kreis Rendsburg-Eckernförde), bygget 1910 of Johann Garleff; $i$ sin tid også offentliggjort som udkast $i$ "Ländliche Bauten in Schleswig-Holstein «, 1914, illustrerende det endelige brud med de preussiske skolebygnings-normer fra 1895.

senteret var Tønderegnen med eksempler på nybyggeri af Bomhoff, Sild, Dinklage, Paulus \& Lilloe, Berlin, professor Anton Huber, Flensborg, Carl Voss, Kiel og Lauritz Thaysen, Tønder.

Udstillingen - hvor der også blev vist eksempler på lignende byggeri i Danmark - viste, at den nye nordtyske arkitektur med stor selvbevidsthed henviste til traditionen, samtidig med at den forblev åben over for samtidens reformtanker. For den nye arkitektgeneration betød begrebet tradition ikke kreativ begrænsning, men snarere en nyorientering i byggeskikken. Ernst Prinz beskrev tradition meget konkret som "mange generationers udkrystalliserede erfaring ", som giver byggeriet de $\mathrm{i}$ indledningen nævnte dyder selvfølgelighed og naturlighed og dermed skaber en tidløs god byggeskik.

Særlig karakteristisk og i bred forstand pædagogisk viste den tyske Heimatschutz-arkitektur sig i tidens skolebygninger, som blev opført i en universel reformpædagogisk ånd og som i stedet for forældet moralpædagogik skulle give eleverne et indbydende sted at lære. Det kunne ske i festlige "skoleslotte " i nybarok stil - som f.eks. AugusteViktoria-skolen og Goethe-skolen i Flensborg eller i en mere enkel form i landsbyskolerne, hvor især kredsbygmester Garleff fra Bordes- 
holm fandt tiltalende løsninger i f.eks. Bissee, Padenstedt, Molfsee, Bordesholm, Kronshagen eller Schönberg. Mellemskolen i by og på land havde også en høj pædagogisk status og blev ikke mindre tilgodeset med hensyn til offentlig støtte. Her skabte bl.a. Thaysen, Bomhoff og Theede fremragende eksempler.

\section{Ny bygningsbevaring i traditionens fodspor}

Hvad der her på den måde blev synligt for hele Slesvig-Holsten, blev særligt bemærkelsesværdigt på Tønderegnen, hvor Baupflege Kreis Tondern fik sat sit stempel på alt nybyggeri. ${ }^{8}$ På den måde fik Tønder en helt særlig tradition for bygningsbevaring og nybyggeri på den gamle bygningskulturs grund - til glæde for de besøgende og turisterne, som her kan beundre en næsten "fuldkommen købstadidyl« $i$ den gamle bydel. I 1972, før det store bygningsbevaringsår 1975, gav Tønders mangeårige museumsdirektør Sigurd Schoubye i tidsskriftet Deutsche Kunst und Denkmalpflege en udførlig beretning om den eksemplariske bygningsbevaring i en nordslesvigsk provinsby: "Erfaringer fra Tønder 1963-1970«. Borgere i Tønder havde allerede i 1962 som en »ren græsrodsbevægelse « ifølge Schoubye dannet en fond for bevaring af gamle bygninger - den endnu aktive Fonden til Bevarelse af gamle Huse. Den satte sig for hvert år at restaurere et hus i den gamle bydel i Tønder. For selv den stemningsfulde gamle bydel i Tønder var i de fremskridtseuforiske 1950'ere og -60'ere med hensyn til plejen af bygningskultur og bybillede ikke mere de lyksaliges uberørte ø. Også her var mangt et fredningsværdigt hus i den gamle bydel ved at forfalde, ved at blive offer for nedrivning eller miste karakteren gennem en alt for tidstypisk modernisering. Selv de for byens bygningskultur så karakteristiske karnapper blev ikke skånet. Allerede i 1950'erne klagede Schoubye over, at karnapper blev fjernet, indgreb tilladt uden modsigelser. Alligevel var indgrebene i den indtil da forholdsvis harmoniske struktur i den gamle by, hvis bevaringsværdige bygningsmasse for det meste stammede fra århundredet efter 1725, på det tidspunkt ikke så drastiske, som det ofte var tilfældet i de gamle byer i Sydslesvig eller Holsten. For i Tønder var bevidstheden om, og dermed også den historisk-æstetiske følsomhed over for hvad der var den passende behandling af et historisk mindesmærke, endnu forholdsvis veludviklet. Her var man påvirket og præget af eftervirkningerne fra den gamle Baupflege Kreis Tondern, som før 


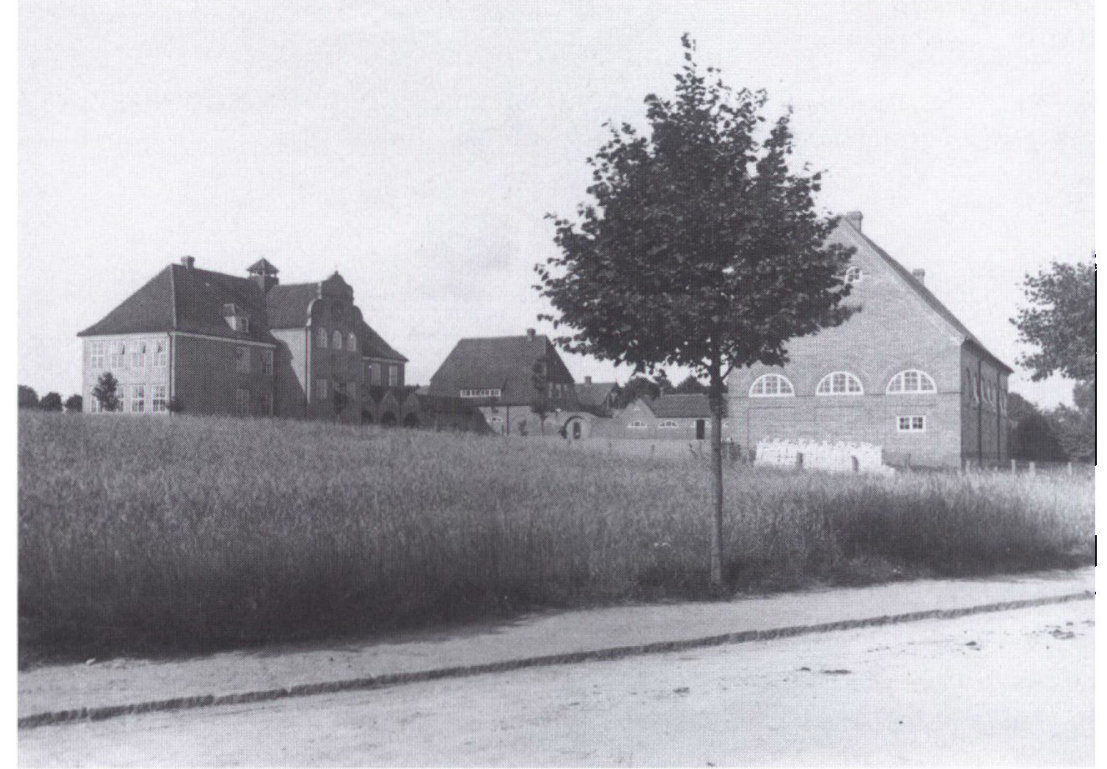

Bordesholm. Foto af den nye folkeskole, bygget 1914 af Johann Garleff. Til højre gymnastiksalen.

1920 havde nydt så stor anseelse langt udenfor egnen - ja, som havde været det tyske mønstereksempel for Heimatschutz.

Også det nye Interessengemeinschaft Baupflege Nordfriesland (IGB) ser sig som arvtagere til og erklærede tilhængere af Baupflege Kreis Tondern. Foreningen blev dannet 1980 og fik $\mathrm{i}$ årene derefter syd for grænsen pustet nyt liv i den gamle idé om bygningskultur. Så Baupflege Kreis Tondern kan på den måde så at sige ses som "mor" til to børn nord og syd for grænsen, 50-60 år senere. Baupflege Kreis Tondern's historiske arkiver bliver i fælles forståelse opbevaret på begge sider af statsgrænsen - for den sydlige dels vedkommende $i$ Husumer Kreisarchiv, for den danske del på lokalarkivet i Tønder.

Dannelsen af IGB Nordfriesland skete da også næsten samtidigt med genopfriskningen af Baupflege-bevægelsens historie i Tønder. I efteråret 1978 på 70-årsdagen for foreningens stiftelse fejrede man på slottet i Husum åbningen af en udstilling, som mindes dette initiativ til bygnings- og kulturvedligeholdelse. Udstillingen blev arrangeret af Kreisarchiv Nordfriesland på initiativ af Dr. Rolf Kuschert, som også sørgede for, at denne dokumentation ikke blot blev vist i Hu- 
Carl Voss: Tegning af en husdor fra det 18. arrhundrede $i$ Slesvig, fra: "Baudenkmäler des alten Bauhandwerks in SchleswigHolstein«, 1929 (samlemappe).
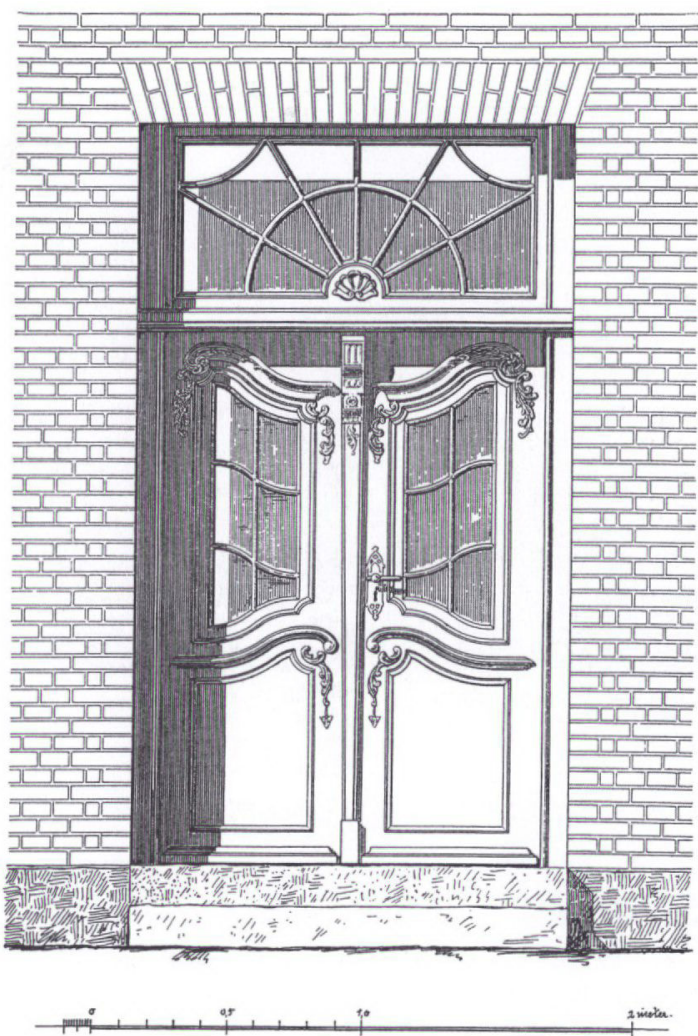

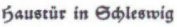

J8. Jabrbunbert

sum, men også kunne sendes på turné til mange andre kredse i form af en smuk og informativ vandreudstilling. I 1977 havde Rolf Kuschert givet en slags forsmag på 70-årsdagen for stiftelsen af Baupflege Kreis Tondern. Amtsarkivet udgav i denne anledning nemlig dels et genoptryk af Baupfleges Vorlegeblätter - det vil sige opmålinger af gamle huse og detaljer til inspiration og efterfølgelse, dels de "gamle notater « fra Baupflege-foreningen, som den rådgivende arkitekt for Baupflege Kreis Tondern, Carl Voss fra Kiel, dengang havde sat i værk, og som siden blev forbillede for det storstilede samleværk Baudenkmäler des alten Bauhandwerks in Schleswig-Holstein, som Carl Voss i 1929 udgav for den slesvig-holstenske Heimatschutz-bevægelse. 


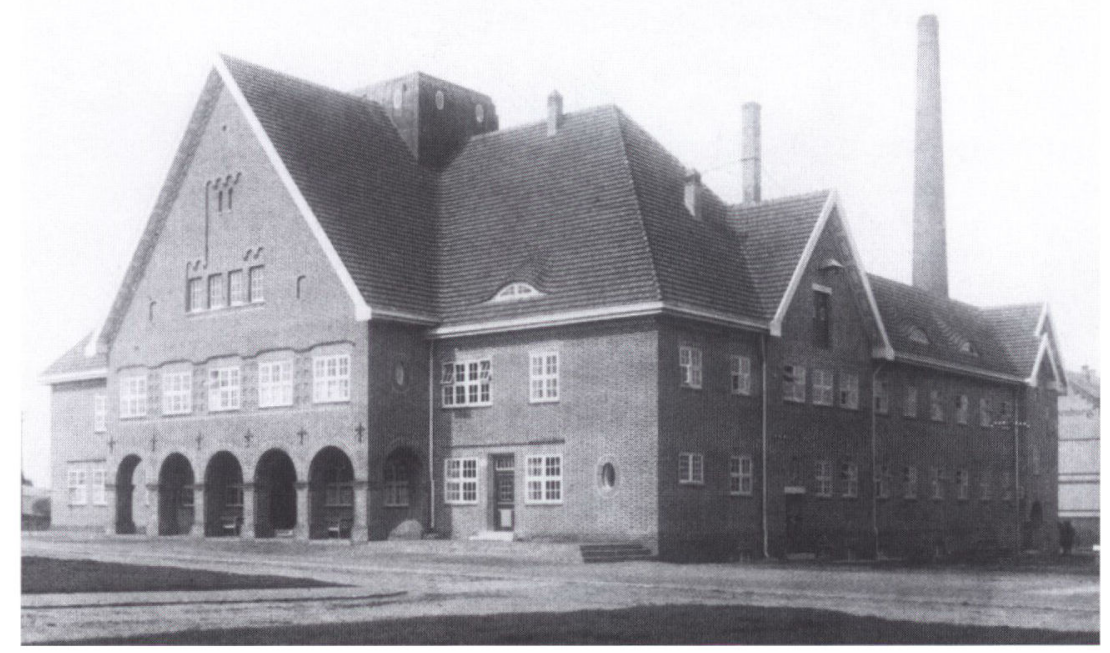

Det $i$ 1907-08 opførte varmbadehus $i$ Westerland på Sild, af Heinrich Bomhoff (ældre foto, nedrevet 1981).

Ligeledes i 1977 gav Rudolf Stehr i Deutsche Volkskalender Nordschleswig en beretning, som han beskedent kaldte den, om "Baupflege $i$ det gamle Tønder amt " og mindede $\mathrm{i}$ undertitlen »Begyndelsen med det nye kredshus 1907 « om, at man egentlig allerede var begyndt med Baupflege-arbejdet godt et år før foreningens officielle stiftelse. 1980 skrev Rolf Kuschert i Heimatkalender Nordfriesland endnu en artikel med et tilbageblik på Baupflege for syv årtier siden, og fremhævede her ligesom Rudolf Stehr den opsigtsvækkende "brandøvelse«, som blev afholdt 4. november 1910 i Tønder efter forbillede fra en tilsvarende brandøvelse i Worpswede - udført af kunstneren Hans von der Ende 1909. Over for byggefolk, bygherrer og brandforsikring skulle "brandøvelsen « demonstrere, at særligt imprægnerede stråtage mindskede brandrisikoen. ${ }^{9}$

I forbindelse med udstillingen i Husum 1979 udkom et rigt illustreret skrift med den bredtfavnende titel Baupflege und Heimatschutz in Nordfriesland. Deri forsøgte forfatteren at skabe sammenhæng mellem praksis og resultater i den gamle Baupflege-bevægelse i Tønder og den nye Heimatschutz-bevægelse. ${ }^{10}$ Trods bygningsbevaringstankens renæssance var den endnu udbredte uvidenhed om den gamle Baupflege- og Heimatschutz-arkitekturs kvaliteter imidlertid året efter skyld i nedrivningen af en af Baupflege Kreis Tondern's pionerbyg- 


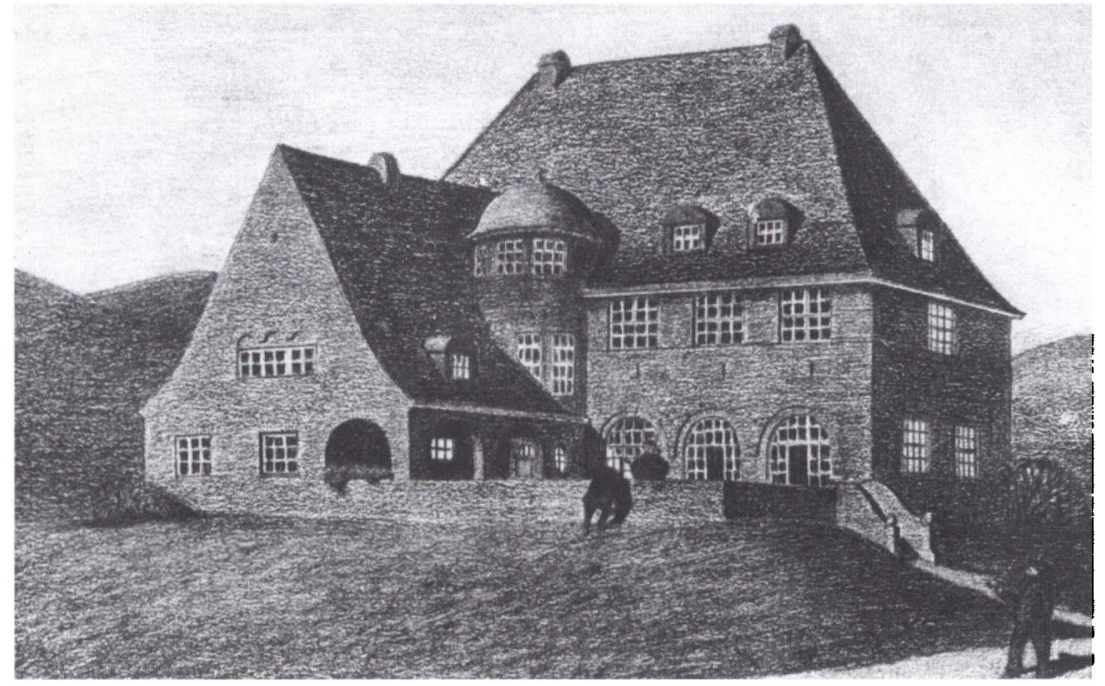

Udkast af Heinrich Bomhoff til hotel i Hörnum pd Sild, 1911.

ninger, nemlig varmbadehuset i Westerland på Sild, opført af Heinrich Bomhoff 1907-08, som et monstereksempel på en ny frisisk arkitektur, bemærkelsesværdig fri for al "påtaget frisisk jovialitet« og med fine biklange fra den samtidige danske teglarkitektur.

\section{Bygningsmonumenter fra Baupflege-tiden}

Det nye ved det nedrevne varmbadehus i Westerland var, ud over den klare farvekolorit, den modige udformning med store uopdelte tagflader, og ikke mindst at disse tage var trukket så langt ned, at den på grund af formålet store bygning ikke virkede så høj, netop mere som et hus. Den høje og brede gavl genopfriskede erindringen om det typisk frisiske gavlhus, blot forbedret og mere aktuel. Tilligemed genindførte arkitekten også det gamle frisiske bygningshåndværks karakteristiske kurvehanksstik over vinduerne, endnu for Baupflege Kreis Tondern havde offentliggjort sine opmålinger og notater med dette tema. Kredsråd Rogge var begejstret for dette bygningsværk, og han hævdede med overbevisning, at denne bygning stod som et "særligt markant vartegn for en bedre udvikling «. Arkitekten havde skabt et mesterværk. I fortsættelse af varmbadehuset kom Bomhoff med et smukt udkast til et frisisk hotel, som desværre ikke blev virkeliggjort, 


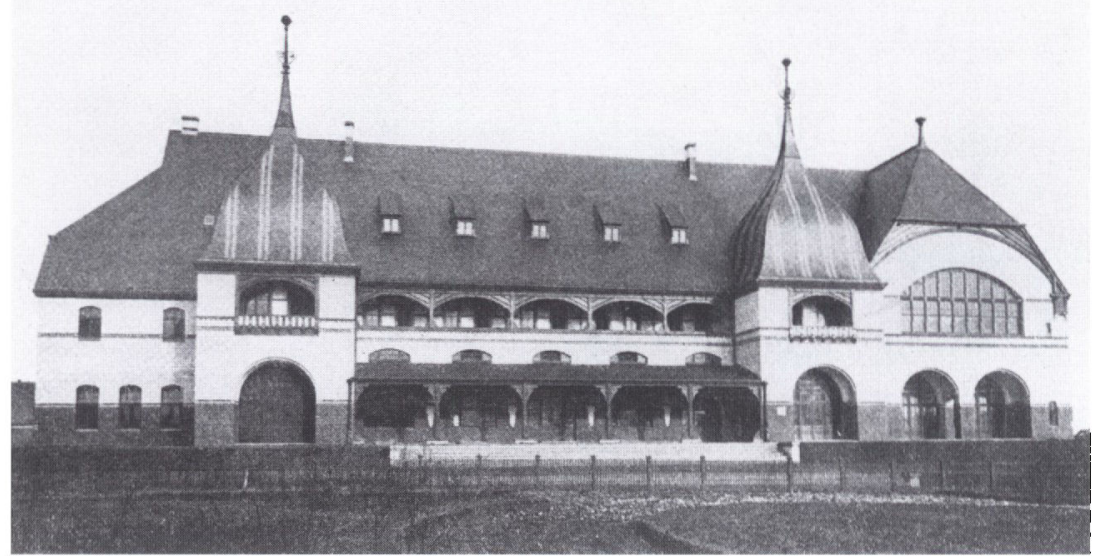

Westerland. Det tidligere kurhus, $i$ dag rådhuset, bygget 1896-98 af J. Vollmer \& H. Jassoy, Berlin. Fra: »Berliner Architekturwelt « 1901.

hvilket heller ikke blev tilfældet med hans suveræne udkast i 1911 til et hotel i Hörnum på Sylt. Med disse bygninger som idealtyper var arkitektur ikke længere blot facade, men på vej til at udvikle »stil«løse og derfor nærmest tidløse kvaliteter som: volumen, bygningsmasse, opdeling, materialefarver og harmoni med landskabet. ${ }^{11}$

Det forekommer absurd, at man i 1980 skilte sig af med et af den her omtalte arkitekturbevægelses mest fremragende vidnesbyrd, netop som denne arkitektur gennem udstillingen i Husum og den dermed forbundne formidling fik en renæssance som forbilledlige bygningsværker. I dag er der almen forståelse for, at Heimatschutz- og Baupflege-arkitekturen er bevarings- ja, fredningsværdig - ikke mindst efter udstillingen Bauen in Backstein. Schleswig-Holsteinische Heimatschutzarkitektur zwischen Tradition und Reform, som 1989 blev arrangeret på slottet i Kiel, og som efterfølgende blev vist flere steder. I udstillingskataloget med samme titel fremhævedes endnu en gang Baupflege Kreis Tondern's væsentlige bidrag til skabelsen af det, vi i dag kalder Heimatschutz-arkitekturen mellem 1907 og 1930-32. ${ }^{12}$

Hvor meget netop varmbadehuset i Westerland dengang betød som eksempel for Baupflege-bevægelsen i Nordfrisland og det gamle Tønder amt, ser man, hvis man sammenligner med det tidligere kurhus i Westerland, i dag rådhuset. Et stort bygningsværk, som arkitekterne Peter Jürgensen og Jürgen Bachmann opførte 1896-98 i en nær- 
Baupflege Kreis Tondern (Neuausführungen).

Weinsfube Max Th. Nissen, Westerland a. Sylf.

Architekt: Heinr. Bomhoff, Hamburg.

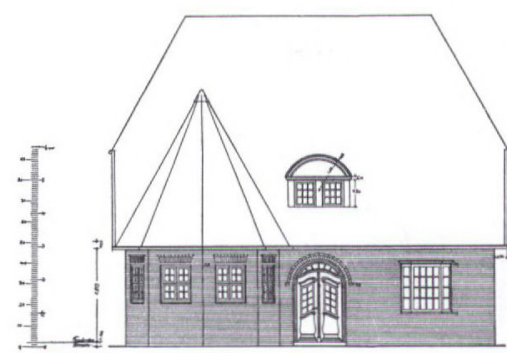

Mosswile.

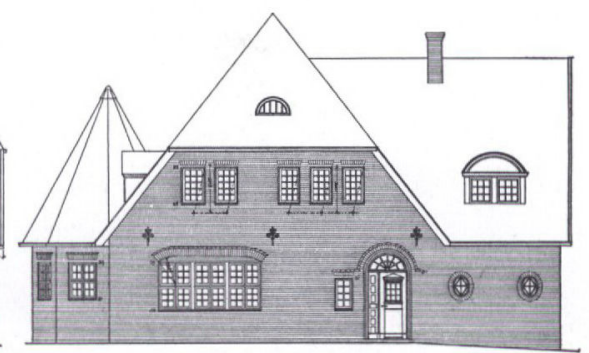

Siiduelle.

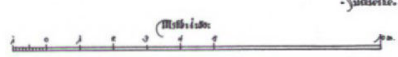

Westerland på Sild. Max Nissens vinstue, vest- og sydsiden. Udkast af Heinrich Bomhoff, fra: Baupflege Kreis Tondern's Neuausführungen blad 8.

mest stedløs stil, som på en noget usikker måde afspejlede forskellige indflydelser, men som dog dengang betød et fremskridt i forhold til det sene 1800-tals badestedsarkitektur. I det tidligere kurbad genkender man bestræbelserne på at frigøre sig fra forpligtelsen over for den historiske "stil«-arkitektur, hvor Jürgensen og Bachmann næsten ikke har vovet at opdele vægfladerne eller at give tårnhattene fysisk volumen. Og endelig de enorme tagflader, næsten et ladetag, som $i$ høj grad brød med badestedsbyggeriets sædvanlige pult- og tjærepaptage. Men det var først varmbadehuset, som ved at anslå en forståelig "frisisk hjemstavnstone" prøvede at sætte forpligtende normer for fornyelsen af arkitekturen $i$ de bygningsmæssigt forvildede badesteder. Endnu et eksempel til efterfølgelse for en bedre badestedsarkitektur blev Max Nissens vinstue i Westerland, hvis hjemstavnsstil stod i eklatant kontrast til den ældre nærmest kulisseagtige byggeskik. Baupflege Kreis Tondern brugte denne bygning som eksemplarisk nybygning og offentliggiorde vinstuen $\mathrm{i}$ sin serie om nye bygningsværker Neuausführungen.

De unge arkitekter i Heimatschutz- og Baupflege-bevægelsen stræbte efter en arkitektur, som uden omstændelige historiske stilcitater udviste både stil og karakter, det vil sige tidløs »hjemlig « karakter. Arkitektur, som både på en hensigtsmæssig måde kunne opfylde alle tidssvarende krav og dog alligevel være poetiske. På den måde skulle byggeriet både på landet og $\mathrm{i}$ købstæderne og ikke mindst på bade- 


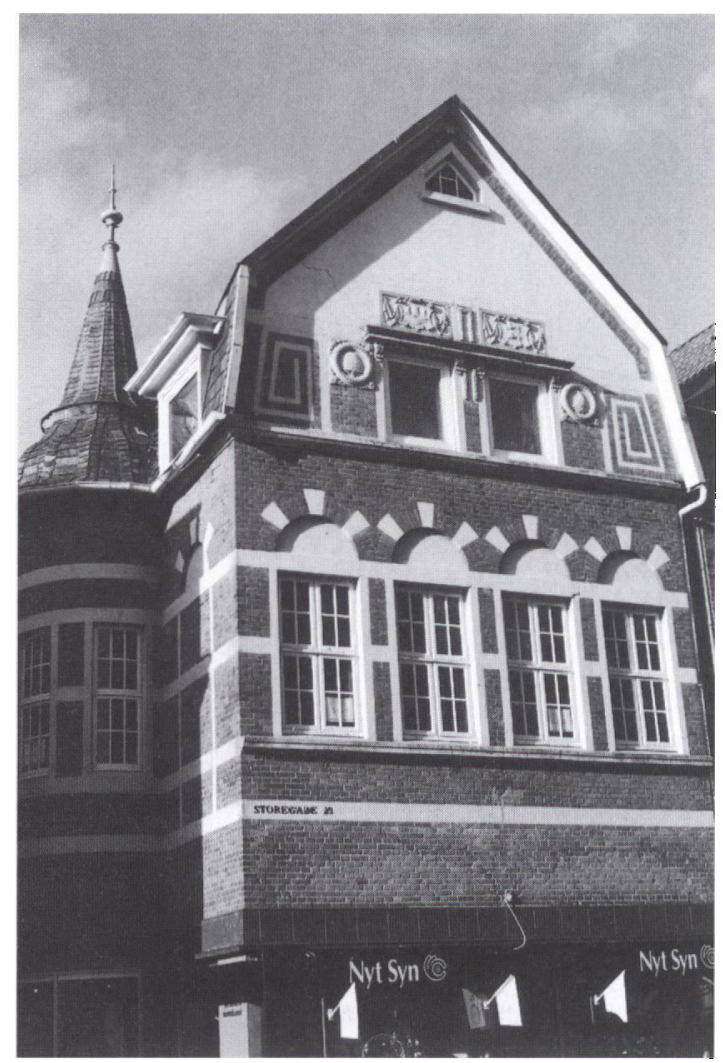

Tonder. Nutidigt foto af den tidligere $» N o r d s c h l e s-$ wiger Bank« Storegade 21, bygget 1904 af Jürgensen og Bachmann, Berlin (stueetagen ændret).

stederne atter genvinde den tidligere omtalte karakterfulde selvfølgelighed og poesien ved det enkle, som havde udmærket den gamle bygningskultur i Slesvig-Holsten frem til omkring 1860. Med god grund havde Carl Zetzsche i sit nævnte samleværk Zopf und Empire von der Wasserkante fremhævet bygningskulturens harmonisk udtrykte billede af kulturel samhørighed i den tidligere tysk-danske helstats fredelige tider. Han gjorde det klart for sine læsere, at man i området nord for Elben atter burde rette blikket mod den omkring 1900 allerede højtudviklede teglarkitektur i det beslægtede Norden, hvis landsdelen i det mindste bygningsmæssigt set skulle blive sig selv igen.

For Tønderegnen lå en sådan nyorientering ikke fjern. Noget, der minder om dansk arkitektur, næsten sprælsk i bygningsfarverne, ser vi i Tønder allerede $1904 \mathrm{i}$ form af den endnu malerisk disponerede 
bygning for den forhenværende Nordschleswiger Bank, som de førnævnte unge arkitekter, Jürgensen og Bachmann, opførte i Storegade. Peter Jürgensen og Jürgen Bachmann var indfødte slesvig-holstenere, den ene fra Dellstedt i Ditmarsken, den anden teglværksejersøn fra Nybøl på Sundeved. De fandt i 1903 sammen som et succesrigt arkitektpar. I Tønder anslog de en ny byggetone, som frigjorde sig fra den rene historiske stilarkitektur. En afdæmpet og på en måde domesticeret jugendstil blev i den omtalte bankbygning frit forenet med mindelser om nordisk arkitektur. Bygningen var på den måde en tydelig kontrast til det teglbyggede nabogavlhus fra 1893, som med sin detaillerede nygotiske formstensarkitektur synes at stamme direkte fra den hannoveranske skoles prøvebog, tilsat sirlige elementer fra tidens dekorative tegl- og terrakotta-renæssance. Denne stil havde til udgangen af 1800-talet præget den nordtyske arkitektur, hvor Jürgensen og Bachmanns bankbygning indvarslede det 20. århundrede, samtidig med at den med sine lette karnapvinduer genopfriskede en gammel Tønder-tradition. Jürgensen og Bachmann, som på den tekniske skole i Eckernförde og derefter ved den tekniske højskole i BerlinCharlottenburg havde gået $i$ en god historisk arkitekturlære, fandt uden besvær vejen fra historisk stilbundethed til fornyende reformarkitektur. Med deres nybyggeri i Slesvig-Holsten ramte de på eksemplarisk vis den nye tone $\mathrm{i}$ byggeriet $\mathrm{i}$ landsdelens Heimatschutz-arkitektur. Dette kan f.eks. ses i den markant beliggende Petri-Kirche i det nordlige Flensborg (1908-09), som med sin fysiske massevirkning kan ses som et moderne og "hjemligt« svar på den højbenede, men dog af reform- og jugendstil prægede St. Jürgen-kirke ved Flensborgs østbred (1904-04, af bygningsinspektør Hossfeld, Berlin og arkitekt A.W. Prale, Flensborg). Virkelig voluminøs og helt igennem afklaret i massevirkningen blev de to arkitekters nybarokke teglbyggede kirkegårdskapel på Friedenshügel i Flensborg, som de efter en stor konkurrence 1908 kunne virkeliggøre 1910-11, en markant bygning med sit store klokkeformede svejfede pyramidetag. Ligeledes blev deres store nybyggerier for statsskolen i Sønderborg (1908/09-11) og den kgl. bygmesterskole i Rendsborg (1909-10) opført i fin hjemlig nybarok teglstensarkitektur. I 1913 byggede de efter en konkurrence det statelige kurhus i Wyk på Føhr, hvor Heinrich Bomhoff allerede 1908 havde opført det henrivende stråtækte Friesenmuseum (Carl-Häberlin-Museum) som en hyggelig prøve på en ny frisisk byggeskik.

Ud over de regionale og frisiske inspirationer var der også familie- 


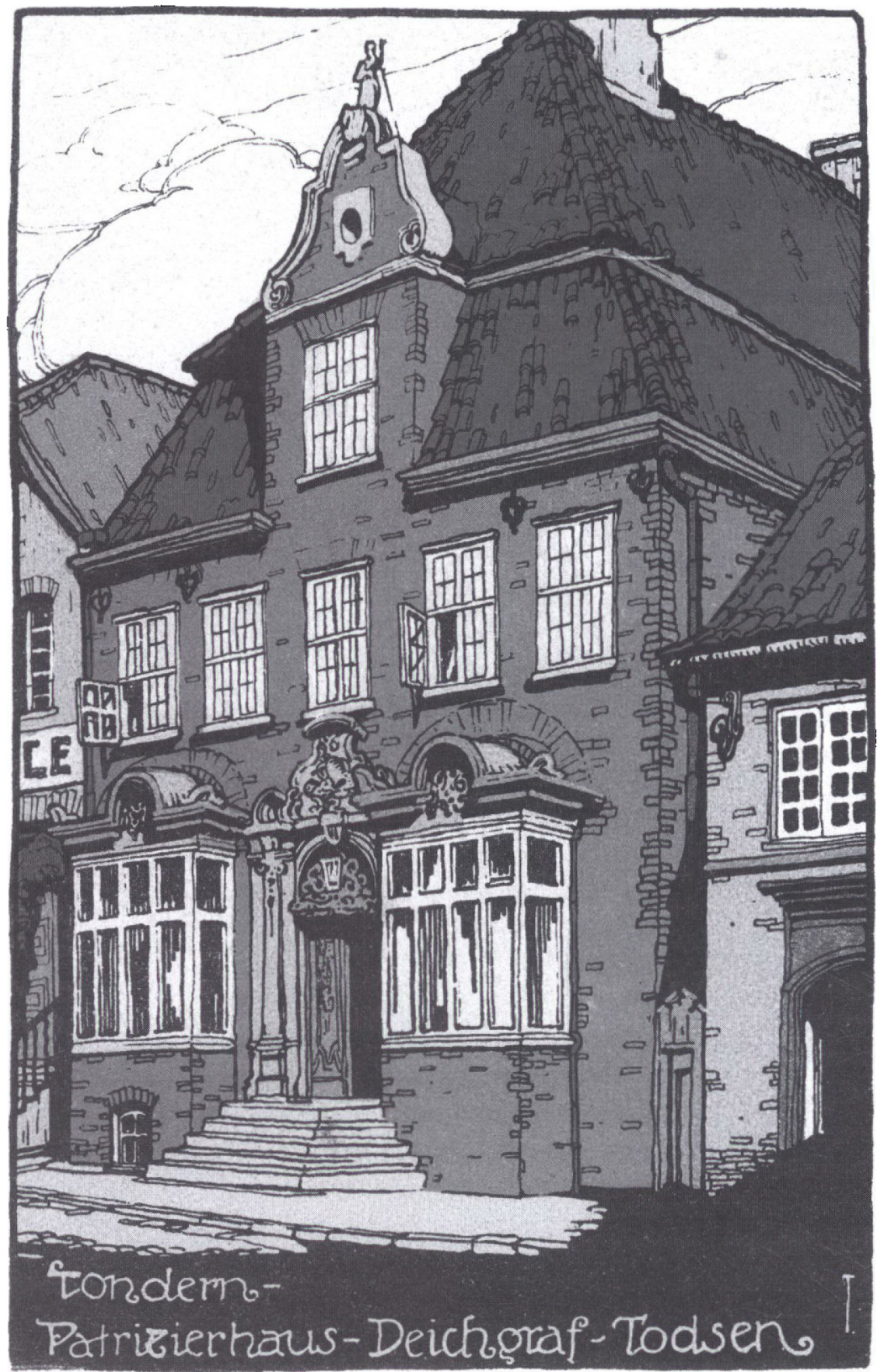

Gammelt kunstner-postkort (farvelitografi) af »Digegrevens Hus", Vestergade $9 i$ Tender, opfort 1777. 
Blad 1 af Baupflege Kreis Tondern's forskrifter: Tegning af en barok murstensgavl fra Tonder by, udfort af arkitekt Carl Voss, Kiel.

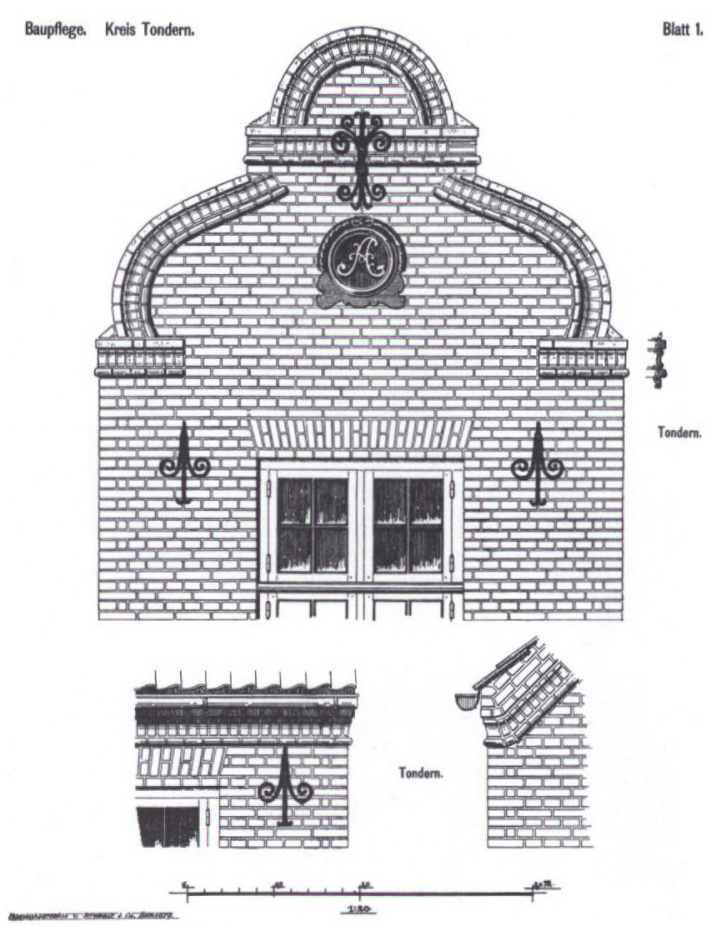

skab mellem kredshuset i Tønder og samtidens hjemligt-poetiske danske murstensarkitektur. Kredssalens store vinduer $\mathbf{i}$ den flade murstensvæg genkendes f.eks. i det nationalromantiske posthus $i$ Aalborg, som den kendte danske arkitekt, Hack Kampmann, opførte samtidigt med kredshuset $i$ Tønder - selv om denne bygning især var inspireret af dansk herregårdsarkitektur fra det 16. århundrede, hvilket ikke ville have givet nogen historisk mening $\mathrm{i}$ Tønder. Til gengæld udstyrede de erfarne teglstensarkitekter, August Dinklage og Ernst Paulus fra Berlin samt den norskfødte Olaf Lilloe kredshuset i Tønder med elementer fra den engelske landstedsarkitektur, som den tyske kulturattaché og arkitekt Hermann Muthesius havde gjort populær i Tyskland. Fra Tønders karakteristiske karnaptradition hentedes til samme bygning med stor naturlighed den tagdækkede vindueskvist, som er beslægtet med det engelske "bay window«. Det berømte senbarokke Digegrevens Hus var her et nærliggende forbillede. I kredshuset genkender man også visse dekorative træk fra det nærliggende gamle Tønder Slot, men et nyt element i arkitekturen var de 


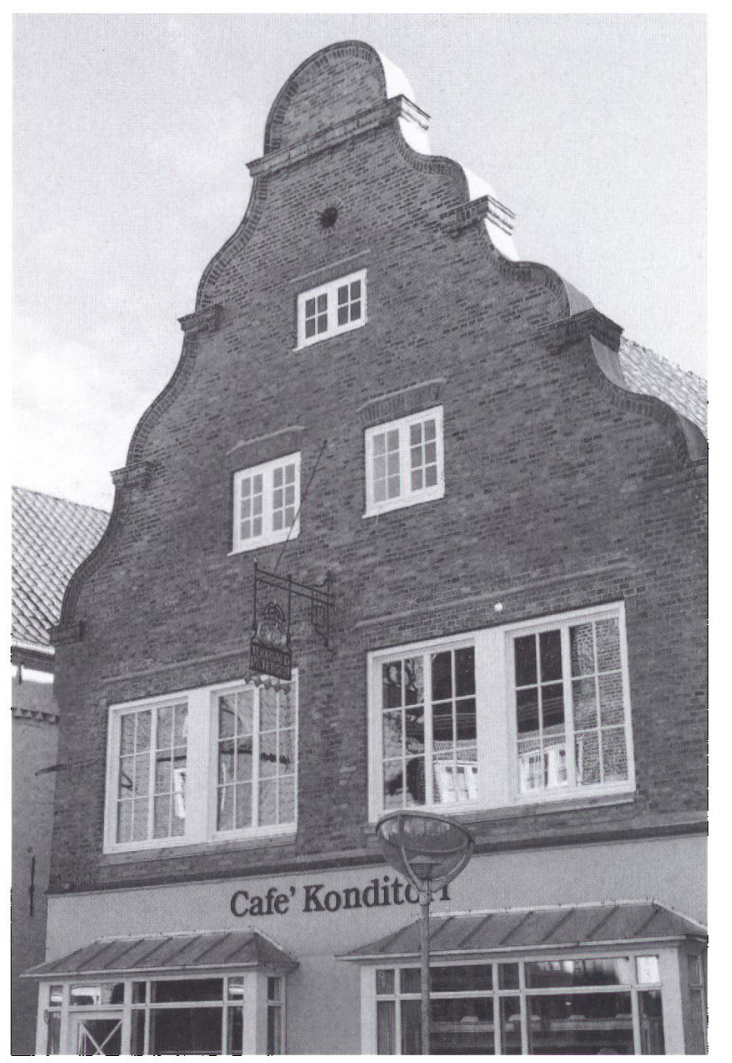

Vestergade, Tonder. Nybarokt hus med svejfede gavle i Baupflege Kreis Tondern's and.

store uopdelte murstensvægge, $\mathrm{i}$ hvilke de hvidmalede småsprossede vinduer efter lokal skik lå i plan. Dertil kommer de ligeledes genoptagne traditionelle bygningsfarvers klare rød-hvid-grønne klang. På alle måder betød Tønder kredshus en resolut afstandtagen fra al egnsfremmed »embedsgotik“. Også i forhold til det af bygningsinspektør Fr. Wilh. Jablonowski i 1901 byggede kredshus i Aabenraa var det arkitektoniske paradigmeskift og bekendelsen til fornyet tradition tydelig. Trods alt bar amtshuset i Aabenraa atter tegltag, men syntes ellers umiskendelig "preussisk-bygningsinspektøragtig« på den formelle måde.

Således var den hjemlige og nyskabende "byggetone « slået an ved Vestkysten - den regionale »dialekt«, som kom til at gælde for alle offentlige bygninger: skoler, præsteboliger, mindre hoteller, forretningsbygninger, gårde og beboelsesejendomme på land og $\mathrm{i}$ by. En 
tidlig prøve på den nye stil var også den indbydende villa Hilde med sine små originale karnaptårne, som kredshus-arkitekterne Dinklage, Paulus \& Lilloe i 1907 byggede i Westerland for kredsråd Rogges søster. Den førnævnte unge arkitekt Heinrich Bomhoff fra Hamburg, som stammede fra Westerland og som blev en meget brugt arkitekt $i$ Baupflege-bevægelsen, formede efterfølgende ud fra dette forbillede en slags idealudkast til nye frisiske bygningsværker - glædelige beviser på, at den enkle, værdige og hjemlige byggeskik kun behøvede en alvorlig stimulans til at skabe overraskende resultater. I klar modsætning til de hidtidige resultater udvikledes nu, som det hed i Baupflege Kreis Tondern's forskrift nr. 15, en "fast besluttet arkitekturretning [...] en retning, som på en utvungen, elskværdig måde knytter sig til egnens hjemlige former: Husene og deres enkeltheder er små mesterværker, som er en pryd for de venlige og hyggelige gader $i$ den lille by og som på gunstig vis tilpasser sig omgivelserne«.

Meget som i den tyske tid og senere blev opført $\mathrm{i}$ Tønder $\mathrm{i}$ den nye arkitektur og byggeskik, skyldes arkitekt Lauritz Thaysen. Men også andre bygmestre fik en chance under de gode byggekonjunkturer $i$ den wilhelminske æras sidste fredsår, f.eks. byg- og murermestrene Evers, Hansen og Nissen.

\section{Gammel og ny byggeskik i Tønder i smuk forening}

Det er især to grundtyper af bygninger, som kom til at præge det nye byggeri i Tønders gamle bydel: For det første det høje og brede tværhus med kraftige gesimser under et mere eller mindre voluminøst mansardtag. For det andet gavlhusene, nogle gange med svejfede helgavle, andre gange høje toetagers gavlhuse med en enkel afvalmet gavlfront. Den sidste var en hustype, der ikke kun egnede sig til de tætbyggede husrækker i den gamle by, men også i de nyere boligstrøg med mere åben bebyggelse. I Tønders mange bygninger fra disse år ser man Digegrevens Hus brugt som ideal og forbillede med tydelig variationsglæde, især i de høje brede bygninger i vellykket nybarok. Meget nybyggeri af kvalitet blev en slags yngre udgaver af Digegrevens Hus. Især blev karnapperne som byggemotiv næsten obligatoriske, både $\mathrm{i}$ forretningsejendomme og $\mathrm{i}$ rene beboelseshuse, hvad enten de var rektangulære eller med smigfag som på digegrevens hus. På den måde blev det prægtige hus, som den velhavende købmand Carsten Richtsen lod opføre i 1777 i moden, men vital stil, indbegrebet 


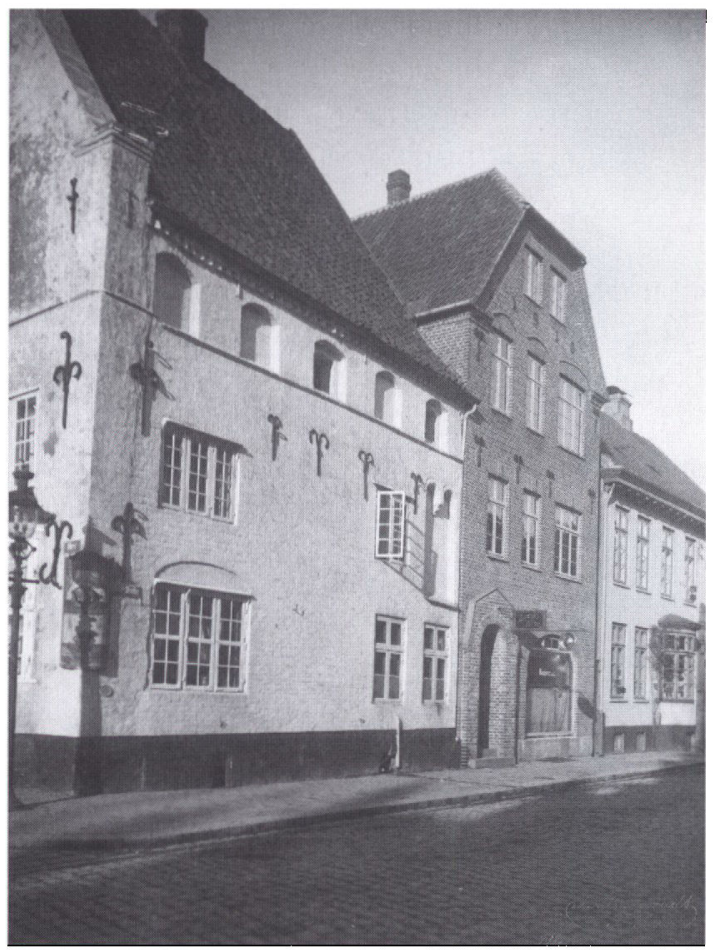

Østergade 2 A, Tonder.

Beboelses- og forretningsbygning for bager Petersen, opfort 1910 af L. Thaysen. Foto 1911.

af komfortabel, repræsentativ boligkultur, et bygningsmæssigt udtryk for en selvbevidst borgerkultur.

Karakteristisk for Digegrevens Hus er også fraværet af pålagte murdetaljer, som f.eks. pilastre og liséner. Til gengæld er pragtportalen og karnapperne festligt dekorerede. Charmen ved karnapperne er, at stuerne får nær kontakt med gaden, så beboerne får mulighed for at følge med $i$, hvad der foregår ude på gaden. Samtidig modellerer de på charmerende vis gadearealet og tilføjer det rytme. Facaden udgør endvidere en ubrudt vægflade, hvori vinduerne på lokal vis ligger i plan som en dekoration med gittersprossernes tidløse skønne hvide farve på den varmrøde murstensbaggrund. Og den krones af den svungne gavlkvist og det optisk tunge mansardtag med de sortglaserede tagsten, som svarer til den barokke tradition både i det danske kongerige og i hertugdømmerne. Især i tagformen ser man, hvor meget den barokke arkitektur er skabt gennem kategorierne masse og legeme - og dertil kommer bygningsfarvernes klare og friske kolo- 
Tonder. Aldre foto af Good-Templar-Logehuset på Viddingherredsgade, tegnet af Lauritz Thaysen. Foto ca. 1911.

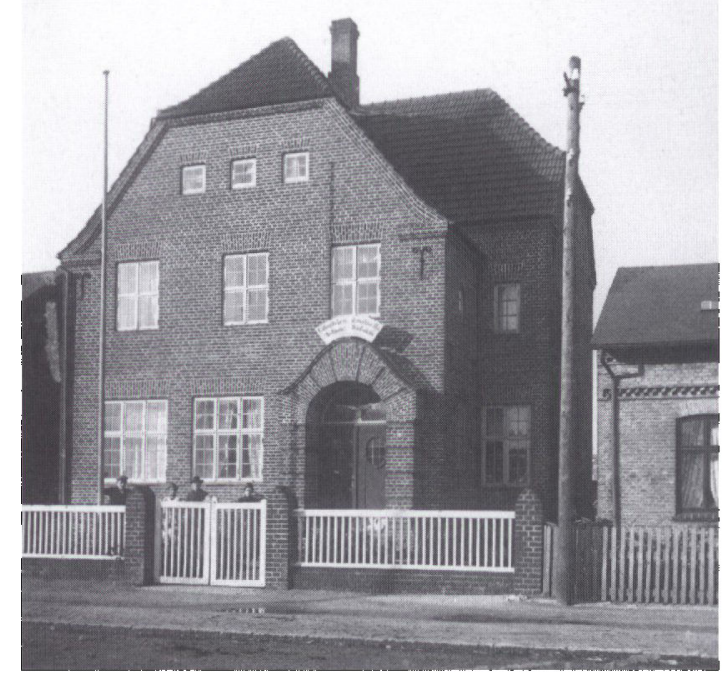

rit. Det er en arkitektur, som også viser karakter fra bag- eller havesiden, således som det fremgår af et blik på huset set fra haven. Alle disse grundformer blev mere eller mindre overbevisende brugt $i$ den lokale Baupflege-arkitektur. I slutningen af den wilhelminske æra finder vi endda »borgerlige« karnapper, direkte kopieret fra digegrevens hus, i et stateligt offentligt bygningsværk som den nye kredsretsbygning, som bygningsinspektør Gyssling opførte 1914-16 i bedste nybarokke teglarkitektur. I Eckernförde byggede Gyssling 1918-22 en meget lignende retsbygning, blot uden tribut til karnaptraditionen fra Tønder.

Tønder og omegn er altså fuld af spændende arkitekturværker, der på den ene side er inspireret af byen og egnens gamle bygninger, men som alligevel tydeligvis er børn af det tidlige 20. århundrede. Det er bygværker, som i lige så høj grad som de gamle udgør en bevaringseller fredningsværdig bygningskultur. Samtidig ophæver byggeriet fra tiden mellem ca. 1910 og 1940 på velgørende vis det ellers så ofte sete brud og stilskift mellem den gamle bydel og den nyere forstadsbebyggelse. Kerne og rand føjes $\mathrm{i}$ Tønder på den måde bygningsmæssigt sammen. Den vej, som Baupflege Kreis Tondern i tysk tid havde angivet, blev nemlig videreført af den dansk-sønderjyske arkitektur og byggeskik fra 1920'erne og -30'erne - som jo også gennem Bedre 


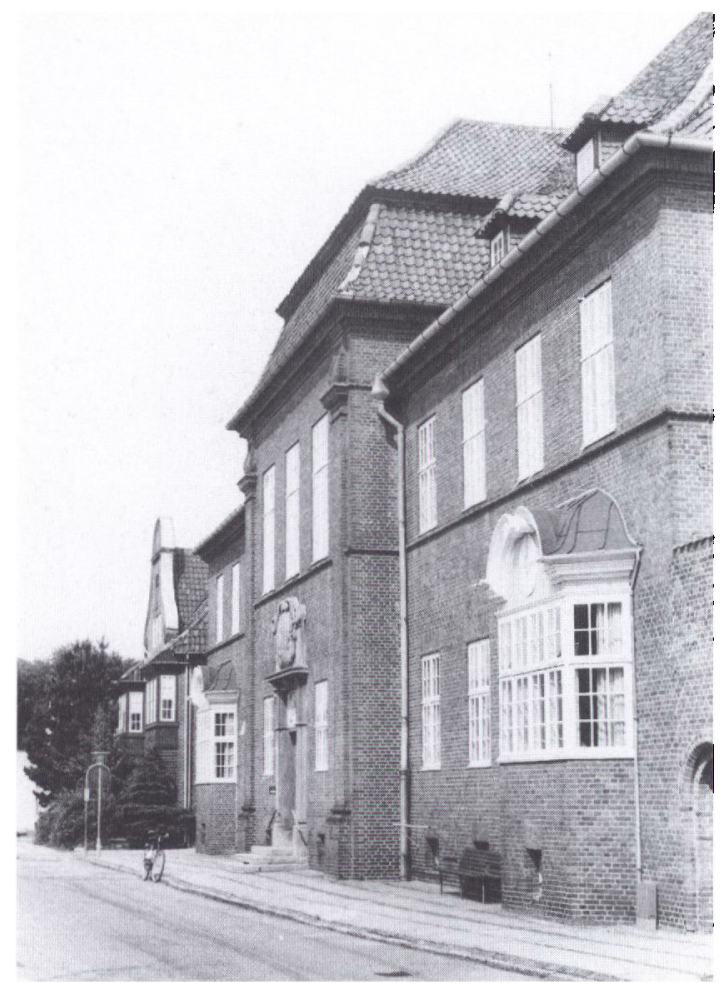

Tonder. Retsbygningen $i$

Norregade, bygget 1914-16

af bygningsinspektor Gyss-

ling, Slesvig med tydelig

reverens til "Digegrevens

Hus«. Foto ca. 1985.

Byggeskik-bevægelsen i høj grad var inspireret af den gamle vestslesvigske byggeskik.

Det nationalstatslige skel fra 1920, som delte det gamle Tønder Amt, fik på den måde ikke de store konsekvenser på byggeriets område - selv om den nye tyske murstens-ekspressionisme i midten af 1920'erne i nogle tilfælde fik nedslag på den tyske side af grænsen. Ikke uden grund havde Ernst Sauermann som repræsentant for den slesvig-holstenske Heimatschutz-bevægelse på ingen måde nationale skyklapper på, da han i sin Schleswig-Holsteinischer Kunstkalender både før og efter 1920 fremhævede bygningsværker, opført af dansksindede arkitekter som Andreas Dall eller Peder Gram som værdifulde bidrag til den nye hjemlige arkitektur i Slesvig-Holsten. ${ }^{14}$ Sauermann ville uden tvivl have skattet den dansksindede arkitekt Jep Finks bygninger ligeså højt - f.eks. den bankdirektørvilla i Tønder med fine hvide blændinger, som Fink i 1912 opførte i »dansk stil« på Ribevej 8 og som helt aldeles passede ind i de lokale omgivelser. Det 


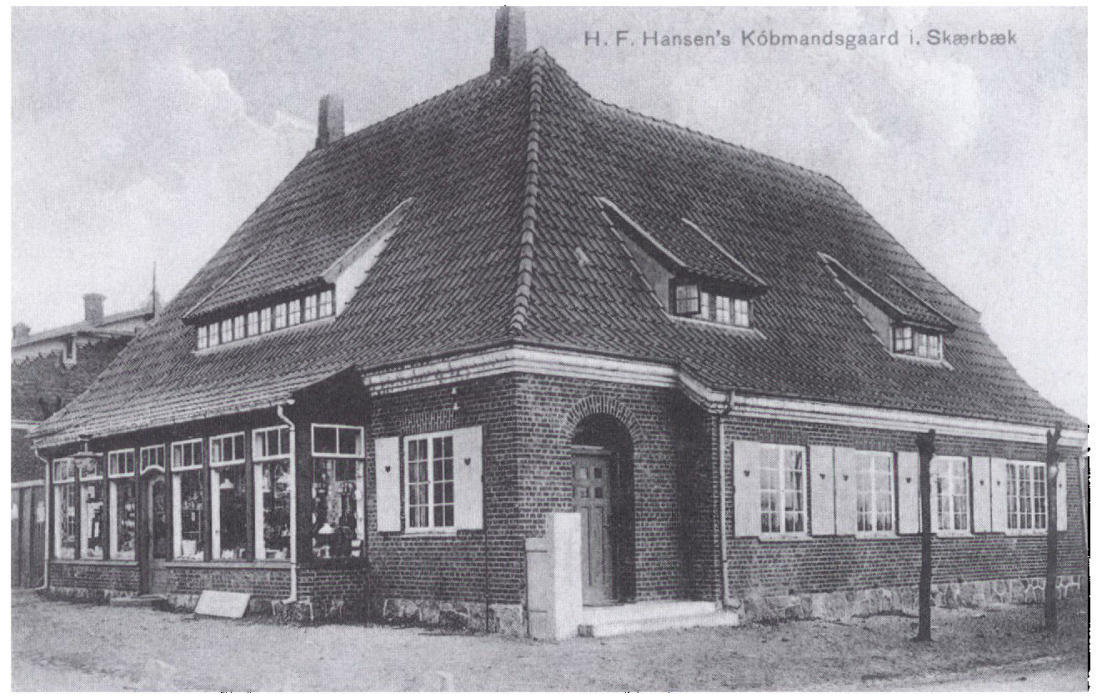

Skærbæk. Gammelt postkort af Hansens Købmandsgård, bygget af arkitekt Kai Gottlob 1909 og offentliggjort samme år i Heimatschutz' Baukatechismus som et weksempel« på godt byggeri på landet.

er også muligt, at Sauermann ville have gengivet det af Martin Nyrop i 1913 byggede danske forsamlingshus Sønderborghus som et godt eksempel. Sønderborghus gjorde i Sønderborg en god figur ved siden af statsskolen, den nye retsbygning fra 1912 og Eugen Fink's officershaveby. Og endelig havde den slesvig-holstenske Heimatschutz-bevægelses føromtalte Baukatechismus allerede i 1909 offentliggjort Hansens villaagtige købmandsgård i Skærbæk, bygget af den danske arkitekt Kai Gottlob, som et godt eksempel på byggeri på landet. Der blev her peget på denne stationsbyforretnings store karnapagtigt udformede butiksvinduer, som på en tiltalende måde gav bybilledet et enkelt, fredeligt præg. ${ }^{15}$

Med delingen af Tønder Amt 1920 afsluttedes den gamle Baupflege-bevægelses virke, men den fandt uden videre en efterfølger syd for Vidåen i foreningen Baupflege Kreis Südtondern, hvor amtsbygmester Karstens fik det arkitektoniske ansvar. Men som sagt videreførtes Baupflege-traditionen i byggeriet også på dansk side, således at man skal se ret nøje efter for at afgøre, hvad der er slesvig-holstensk Heimatschutz-byggeri eller dansk byggeri i Bedre Byggeskiks tegn. ${ }^{16}$ Det smukkeste eksempel på denne byggeskiks kontinuitet møder vi 


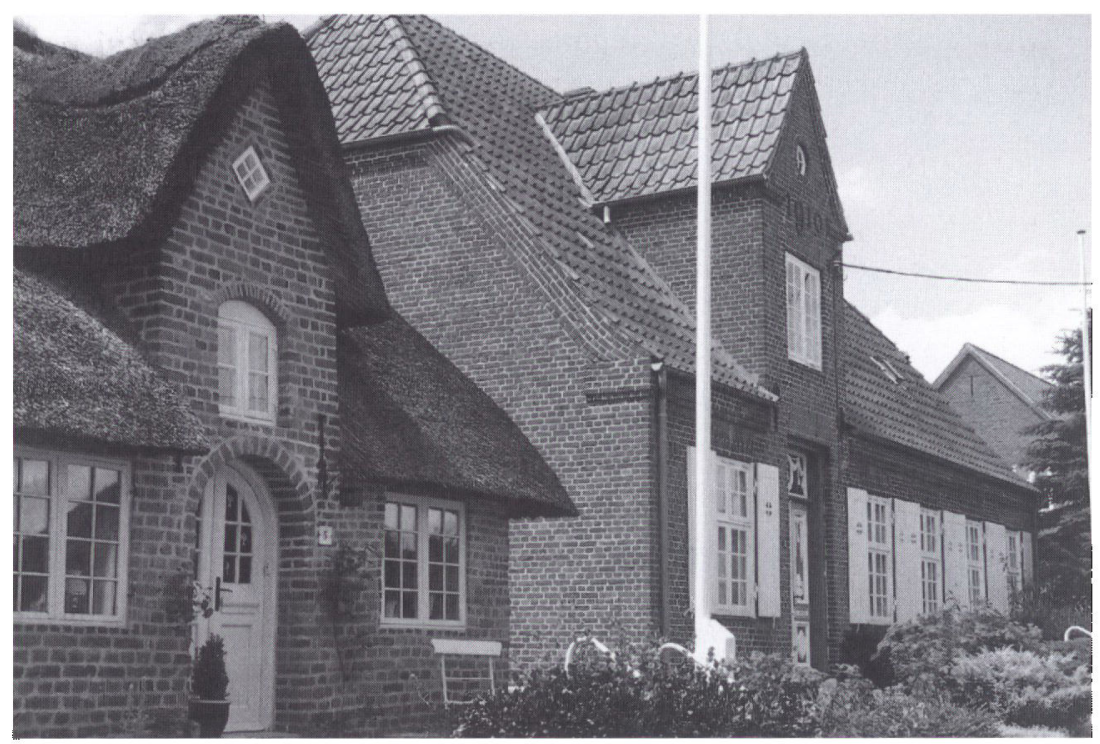

Sønderbyvej i Møgeltender: Aldre 1700-tals huse og godsinspektør H.C. Davidsens huse fra hhv. 1910 og 1923. Et eksempel på bygningskulturel kontinuitet fra det 18. århundrede til Baupflege-tiden og "Bedre Byggeskik efter genforeningen.

nok i Møgeltønder. Ved Sønderbyvej, som støder op til den berømte Slotsgade, ser vi for foden af det mægtige kirketårn et utroligt fortællende bygnings-ensemble, bestående af to gamle Møgeltønderhuse med "friserkviste" og karnapper: Godsinspektør H.C. Davidsens første bygning, Sønderbyvej 3 i typisk Baupflege-stil fra 1910 og hans to Bedre Byggeskik-prægede småhuse med kviste og karnapper, Sønderbyvej 9-11 fra 1923. Karnapper og gavlkviste er fælles ledemotiv, kun målene ændrer sig, og det udtrykkeligt danske dukker op i de kraftige hvidtede gesimser. Ved siden af disse fire huse står som noget fremmedartet et typisk nordtysk trempelhus fra århundredskiftet.

Baupflege Kreis Tondern udgav som propaganda for sagen både gode eksempler på nybyggeri og de førnævnte forskrifter, tegninger og opmålinger af ældre bygninger på egnen til inspiration og efterfølgelse. Det afgørende forarbejde til disse tekniske tillægsblade udførtes af en række lokale fotografer gennem optagelser af egnens traditionelle bygnings-, bolig- og folkekultur. Uden disse ville Baupflege-arbejdet næsten ikke have været muligt. I Tønder var det frem for alt realskolelærer Theodor Möller fra Kiel, som på få år stillede et arkiv på 
over 1000 pladeoptagelser til disposition for Baupflege Kreis Tondern. Takket være dette materiale kunne arkitekt Carl Voss udarbejde dels de smukke tegninger af gamle frisiske bygningsformer, de nævnte forskrifter, dels en række opmålinger, hvis værdi er blevet mere kendt efter genoptrykket fra Husum $1978 .^{13}$

Lauritz Thaysen, Tønders førende arkitekt $\mathrm{i}$ disse år, og som havde et godt forhold til kredsråd Rogge, har helt sikkert også gjort brug af disse eksempelblade. Thaysen var født i Tønder, årgang 1880, uddannet på den tekniske skole i Eckernförde og akademisk videreuddannet på den tekniske højskole i Darmstadt under arkitekturlærer Professor Pützer. I 1908 slog han sig ned i Tønder som privat arkitekt og var siden da bygmesteren i Tonder, hvor han for denne by blev, hvad f.eks. Bomhoff var for Sild og Før. I konkurrencen om Tønder Realskole i 1908 vandt Thaysen knebent foran Bomhoff, som også var blevet nr. 2 i konkurrencen om kredshuset. Og ligeledes i 1908 fik Bomhoff en andenplads efter Jürgensen og Bachmann i konkurrencen om statsskolen i Sønderborg. I begyndelsen, før grundlæggelsen af Baupflege Kreis Tondern, havde Thaysen "som så mangen en byggende person i de mindre byer [...] arbejdet med enhver mulig og umulig byggestil alt efter ønske og humør«, som det vel bevidst overdrevet blev skrevet i Neuausführungen, hvor hans senere forbilledlige nybygninger blev præsenteret. Udviklingen fra den stilefterlignende officielle arkitektur til den efterfølgende hjemlige byggeskik er særligt anskuelig i det daværende preussiske lærerseminariums, det senere Tønder Statsseminariums, kompleks. I tydelig kontrast til den gamle bygning fra 1904-05, som endnu er præget af den senpreussiske stil, blev det første anneks tilføjet i 1915 efter udkast af Thaysen i den modne Heimatschutz-arkitekturs afklarede form og i bygningsmæssig harmoni med de omkringliggende gamle historiske bygninger. Under dansk ledelse blev der i 1932 yderligere tilføjet en tilbygning, som harmonerede fint sammen med Heimatschutz-tilbygningen fra 1915.

I Tønder udarbejdede Lauritz Thaysen også i 1920 - endnu som medlem af BDA - et udkast til en fremsynet om- og tilbygningsplan for den i 1913 af Hans Ross opførte realskole i Bredsted, som ville betyde en kraftig udvidelse af den solide og festlige skolebygning, men med bibeholdelse af dens karakter. Ombygningen blev ikke til noget, men i stedet kom Thaysen i 1922-23 til at tegne folkehøjskolen samme sted - som et eksempel på rækken af »hyggelige « landlige 
skolebygninger, som Dinklage, Paulus \& Lilloe havde indledt med folkehøjskolen i Tinglev 1908.

\section{Afslutning}

Den danske arkitektstand kendte allerede Heimatschutz-arkitekturen og Baupflege-bevægelsen i Slesvig-Holsten længe før grundlæggelsen af Landsforeningen for Bedre Byggeskik 1915. Først og fremmest havde den unge generation af arkitekter stiftet bekendtskab med Tønderegnen og uden tvivl også med Baupflege Kreis Tondern's arbejde gennem opmålingsrejser i 1907 og 1909. Desuden blev det tyske arbejde gentagne gange omtalt i det indflydelsesrige danske tidsskrift Architekten. Heri offentliggjorde arkitekt- og senere bygningsrådgiver ved magistraten Werner Jakstein fra Altona i 1912 en artikel med den kortfattede titel »Byggehjælp«, illustreret med eksempler på nye bygningsværker og udkast - en artikel, som man må formode blev læst med stor interesse. ${ }^{17}$ Især blev det derved for alvor kendt, at man på den tyske side $\mathrm{i}$ årevis havde udført et arbejde, der svarede til den danske arkitektforenings i 1908 oprettede Tegnehjælp (hvor bygmestre kunne få rettet deres tegninger til gode danske huse). ${ }^{18}$

Artiklen er bearbejdet af Peter Dragsbo, Museet på Sønderborg Slot.

NOTER

1. Ernst Prinz, om Heimatschutz (foredrag for amtsrådet i Bordesholm) i: Die Heimat 21:1911; genoptrykt i: Hans-Günther Andresen: Bauen in Backstein. Schleswig-Holsteinische Heimatschutzarkitektur zwischen Tradition und Reform, Schriften aus dem Schleswig-Holstenischen Landesbibliothek 8, Heide 1989, s. $222 \mathrm{ff}$. samt Karl Meyer: Ländliche Bauten in Schleswig-Holstein. 100 Musterentwurfe, Schleswig-Holsteinische Landesverein für Heimatschutz, Lübeck 1914, s. 5. Dertil fra dansk side: Peter Dragsbo: Mellem regionalisme og nationalisme. Ballum Slusekro og den slesvigske "hjemstavnsstil«, i: Kulturens nationalisering. Et etnologisk per- spektiv på det nationale, udgivet af Bjarne Stoklund, København 1999, s. 173-189 samt Peter Dragsbo: Ud med Italien, leve Møgeltønder, i: Sønderjysk Månedsskrift 10:2003, s. 244-253. Samme: Eksempler på hjemstavnsstilen i Sønderjylland, sst. s. 254-260. Inger Lauridsen: Lauritz Thaysen, arkitekt i Tonder 1904-1930, sst. s. 261272. Jørgen Toft Jessen: Peter Gram og andre arkitekter i Haderslev 19091937, sst. s. 273-287. Ingolf Haase: Godsinspektør Davidsen som arkitekt, sst. s. 288.

2. Paul Schultze-Naumburg: Kulturarbeiten, Bd.1-9, Kunstwart-Verlag München $1902 \mathrm{ff}$.

3. Carl Meyer: Das Bauen af dem plat- 
ten Lande und in den kleinen Städten. Baukatechismus mit Bildern, Schleswig-Holsteinische Landesverein für Heimatschutz, Lübeck 1909 (3. Oplag 1923); K(C)arl Meyer: Ländliche Bauten in Schleswig-Holstein, som note 1.

4. Schencke, Prof. Dipl.-Ing: Den kongelige Tekniske Skole i Eckernförde, i: Schleswig-Holsteinischer Kunstkalender 1918-19, s. 83.

5. Paul Mebes: Um 1800 . Architektur und Handwerk im letzten Jahrhundert ihrer traditionellen Entwicklung, München 1908 (2. og 3. oplag 1918 og 1920).

6. Carl Zetzsche: Zopf und Empire von der Wasserkante, Stuttgart 1908; samme: Die dänische Ausstellung im Berliner Kunstgewerbemuseum, i: Architektonische Rundschau 4:1911.

7. Jvf. Hans-Günther Andresen, Bauen in Backstein ..., som anm. 1, særlig s. 86-94; Ulrich Schulte-Wülwer: Ernst Sauermann und die Anfänge der Heimatschutzbewegung in Flensburg, $i$ : K.O. Kahrmann og U. Schulte-Wülwer: Flensburg um die Jahrhundertwende, Heide 1984, s. $15 \mathrm{ff}$.

8. Jvf. Friedrich Rogge, Drei Jahre Baupflege im Kreis Tondern, i: SchleswigHolsteinischer Kunstkalender 1912, s. 17-26; Carl Voss og Friedrich Rogge: Baupflege Kreis Tondern, særtryk af Kreiskalender für den Kreis Tondern 1909; Rolf Kuschert, Baupflege Kreis Tondern. Landschaftsgebundenes Bauen im Kreis Tondern am Anfang unseres Jahrhunderts, i: Die Heimat 84:1977, s. 254-262. Samme: Baupflege vor sieben Jahrzehnten, i: Zwischen Eider und Wiedau. Heimatkalender für Nordfriesland 1980 , s. 79-90; Hans-Günther Andresen: Baupflege und Heimatschutz in Nordfriesland. Landschaftsgerechtes Bauen zwischen Reform und Tradition, Schriften des Kreisarchivs Nordfriesland 3, Husum 1979, samme: Bauen in Backstein ..., som anm. 1, især s. 7994.

9. Rolf Kuschert, som note 8 , Rudolf Stehr: Baupflege im alten Kreis Tondern, i: Deutscher Volkskalender Nordschleswig 1977, s. 48-61.
10. Hans-Günther Andresen: Baupflege und Heimatschutz in Nordfriesland, som note 8. Samme: Heimatschutzarkitektur in Nordfriesland, i: Das grosse Nordfriesland-Buch, udgivet af Thomas Steensen, Hamburg 2000, s. 314-321.

11. Jvf. Hans-Günther Andresen: Das Warmbadehaus in Westerland - Ein bedeutendes Denkmal neuer friesischer Architektur des frühen 20. Jh. soll fallen. Ein Rückblick auf einige Stationen auf dem Wege zu neuer Baugesinnung in Nordfriesland, $i$ : Die Heimat 11/12, 1980, s. 392-417.

12. Jvf. Hans-Günther Andresen: Bauen in Backstein, som note 1. Samme: Von schlesvig-holsteinischer Heimatschutz-Architektur, i: Stein auf Stein. Ländliches Bauen zwischen 1870 und 1930, udgivet af G. Dahms, G. Wiese og R. Wiese (Arbeit und Leben auf dem Lande 6), Freilichtmuseum am Kiekeberg, Hamburg 1999, s. 207-236.

13. Baupflege Kreis Tondern, genoptryk af Vorlegeblätter og Altaufnahmen, med forord af Rolf Kuschert, Schriften des Kreisarchivs Nordfriesland 2, Husum 1978. Jvf. Reinhard Bordel: Alter Baukultur auf Föhr, Schriften aus dem. Dr. Carl Haeberlin - Friesenmuseum, Wyk auf Föhr, Hft. 4/ny udg., Husum 1988; Carl Voss: Meisterwerke aus dem nordfriesischen Baukunst (genudg. a. Nordfriesisches Institut Bredstedt) Bredstedt 1975; Carl Voss: Denkmäler des alten Bauhandwerks in Schleswig-Holstein, 88 tavler signeret af arkitekt C. Voss, udgivet af Schleswig-Holsteinische Landesverein für Heimatschutz, Kiel 1929 (genoptryk Bernd Schramm-Verlag, Kiel).

14. Jvf. Ernst Sauermann: Zur heimischen Architektur, i: Schleswig-Holsteinischer Kunstkalender 1912. Heri udkast af $P$. Gram til alderdomshjem i Aabenraa (ikke opført) og Haderslev Bank i Toftlund. Se også: SchleswigHolsteinisches Jahrbuch 1927: afbildning af Duborgskolen i Flensborg af Andreas Dall.

15. Baukatechismus, som note 3, s. 45; jvf. Christian Kaatmann: Byggestil og byggeskik - Nationale strømninger $i$ 
senderjysk arkitektur 1850-1940, Institut for Grænseregionsforskning, Aabenraa 1988, s. 92. Jfr. Peter Dragsbo: Eksempler på hjemstavnsarkitektur i Sønderjylland, se note 1.

16. Jfr. Christian Kaatmann, som note 15; Hans Peter Svendler Nielsen: Bedre Byggeskik, i: Erhvervshistorisk Årbog 1979, Meddelelser fra Erhvervsarkivet 29, Århus, S. 89-126; Povl Leckband Kontrast oder Gleichklang? Konzepte und Schaffen dänischer Architekturkollegen Zieglers, i: Paul Ziegler -
Magistratsbaurat in Flensburg 19051939, udgivet af Broder Schwensen og Bernd Köster, Gesellschaft für Flensburger Stadtgeschichte, Kl. Folge 29), Flensborg 1998, s. 88-97; se også: Peter Dragsbo og Kirsten Frederiksen: Harald Peters 1891-1951. Bedre Byggeskik og bungalow'er, Esbjerg 1991.

17. Werner Jakstein: Byggehjælp, i: Architekten. Meddelelser fra Akademisk Arkitektforening 15, 6: 1912, s. 57-65.

18. Peter Dragsbo: Ud med Italien, leve Møgeltønder, se note 1. 